\title{
Photosynthesis and nitrogen fixation during cyanobacteria blooms in an oligohaline and tidal freshwater estuary
}

\author{
Yonghui Gao*, Judith M. O'Neil ${ }^{* *}$, Diane K. Stoecker**, Jeffrey C. Cornwell
}

University of Maryland Center for Environmental Science, Horn Point Laboratory, PO Box 775, Cambridge, Maryland 21613, USA

\begin{abstract}
Rates of photosynthesis and nitrogen fixation were measured along with species composition and plankton biomass during cyanobacteria blooms in the upper Sassafras River, a poorly buffered tidal freshwater tributary of Chesapeake Bay, USA. The mixed species composition of the cyanobacteria consortium appears to allow these species to take advantage of temporal variations in dissolved inorganic carbon (DIC) and dissolved oxygen (DO) to fix carbon (C) and nitrogen $(\mathrm{N})$ under conditions limiting to most phytoplankton. At the early stage of the bloom, diazotrophic (nitrogen fixing) cyanobacteria species became dominant, likely as a consequence of nitrogen limitation; both rates of $\mathrm{N}_{2}$-fixer biomass-normalized $\mathrm{N}_{2}$ fixation and chlorophyll a-based photosynthesis increased with irradiance during this bloom stage. When the bloom reached peak biomass, photosynthetic carbon uptake and oxygen production resulted in DIC depletion and oxygen oversaturation. The constraint of oxygen on nitrogenase activity and concomitant $\mathrm{C}$ limitation on photosynthesis caused inhibition of $\mathrm{N}_{2}$ fixation in the light during bloom peaks. $\mathrm{N}_{2}$ fixation in the dark period accounted for $\sim 40 \%$ of daily $\mathrm{N}_{2}$ fixation when $\mathrm{pH}$ and DO were extremely high, and cyanobacteria species known to fix $\mathrm{N}_{2}$ in the dark were dominant in the consortium at these times. The presence of cyanobacteria species with different environmental tolerances resulted in bloom persistence under limiting conditions for most eukaryotic phytoplankton. $\mathrm{N}_{2}$ fixation by cyanobacteria consortia is an important component of the nitrogen cycle in some oligohaline and tidal freshwater estuaries.
\end{abstract}

KEY WORDS: Cyanobacteria - Chesapeake Bay nitrogen fixation - Primary productivity · Nitrogen limitation $\cdot \mathrm{pH} \cdot$ Carbon availability $\cdot$ Dissolved oxygen

Resale or republication not permitted without written consent of the publisher

\section{INTRODUCTION}

Cyanobacteria blooms often cause degradation in water quality, and pose a toxic threat to human health and aquatic production in the oligohaline and freshwater reaches of some temperate and eutrophic estuaries as well as in marine and freshwater ecosystems (Codd et al. 2005). Cultural eutrophication, together with global warming, may support the global expansion of cyanobacteria and increase the likelihood of blooms in temperate estuaries (Paerl 2008, Paerl \& Huisman 2008, O'Neil et al. 2012). Interestingly, in contrast to many other types of harmful algal blooms that tend to be monospecific, estuarine cyanobacteria blooms often consist of a mixture of several species.

Due to their specific physiological mechanisms, cyanobacteria can successfully compete for dissolved inorganic carbon (DIC), nitrogen (N), and phosphorus (P) under bloom conditions. During dense blooms, particularly in poorly buffered oligohaline and fresh waters, DIC can limit photosynthesis as inorganic carbon is quickly consumed. $\mathrm{CO}_{2}$-concentrating mechanisms allow cyanobacteria to photosynthesize and grow when DIC levels are limiting to most other phytoplankton (Mogelhoj et al. 2006). Another impor- 
tant physiological attribute of many bloom-forming cyanobacteria is their ability to perform $\mathrm{N}_{2}$ fixation, converting dissolved $\mathrm{N}_{2}$ gas to ammonium and ultimately biomass (Capone et al. 2009). Under N-limited conditions, $\mathrm{N}_{2}$ fixers may out compete non- $\mathrm{N}_{2}-$ fixing phytoplankton, support bloom proliferation, and bring new $\mathrm{N}$ into aquatic ecosystems (Paerl 2008). To protect the nitrogenase enzyme from oxygen produced by photosynthesis, several different strategies occur among cyanobacteria, including protection of nitrogenase within specialized nonphotosynthetic cells (heterocysts) and nighttime $\mathrm{N}_{2}$ fixation in non-heterocystous cyanobacteria (Fay 1992). Moreover, cyanobacteria may alleviate potential P limitation by luxury uptake and storage of $\mathrm{P}$ (Krauk et al. 2006), and utilize dissolved organic $P$ pools (Dyhrman \& Haley 2006) as well as surfaceadsorbed phosphate (Sañudo-Wilhelmy et al. 2004). Thus, as a group, cyanobacteria are well adapted to proliferate under dense bloom conditions unsuited to many other phytoplankton, conferring a competitive advantage.

Cyanobacteria blooms also modify the environment in ways that affect their photosynthesis, nitrogen fixation, and growth. Especially in low-carbonate buffered systems, the high rates of photosynthesis, together with the efficient acquisition of DIC, can result in dramatic $\mathrm{pH}$ elevation and DIC depletion during cyanobacteria blooms. Oxygen production in the day during dense blooms can dramatically enhance intracellular oxygen concentrations and release oxygen into the water column, all of which can suppress nitrogenase activity in many cyanobacteria (Bergman et al. 1997, Capone et al. 2009). Bloommediated changes in water chemistry can affect carbon fixation, cellular $\mathrm{C}: \mathrm{N}$ ratios, and phytoplankton species composition, which in turn can affect $\mathrm{N}_{2}$ fixation and diel cycles of physiological processes (Engel et al. 2008, Fu et al. 2008).

$\mathrm{N}$ loading into most temperate coastal ecosystems is high, potentially minimizing the role of $\mathrm{N}_{2}$ fixation; as a result, cyanobacteria $\mathrm{N}_{2}$ fixation has not been considered in most estuarine ecosystem models (Boynton \& Kemp 2009). However, blooms of noxious cyanobacteria occur frequently in the tidal freshwater and oligohaline zone (salinity $<3$ ) of tributaries (Tango \& Butler 2008), as well as in the Baltic Sea and some other low-salinity coastal ecosystems ( $\mathrm{O}^{\prime} \mathrm{Neil}$ et al. 2012). In the tidal freshwater region of the Sassafras River, a tributary of Chesapeake Bay, cyanobacteria assemblages contain a diversity of co-occurring species, with $\mathrm{N}_{2}$ fixers and non- $\mathrm{N}$ fixers both present. The frequency and abundance of cyanobacteria blooms have been increasing during recent decades in the upper river (W. Butler unpubl.). This system presents a good opportunity to determine how changes in environmental variables may affect cyanobacteria blooms, including species succession and the physiological responses of the cyanobacterial consortia to unsuitable conditions (low N:P ratios and DIC, high $\mathrm{pH}$ and dissolved oxygen [DO]).

During summer blooms in 2010, seasonal changes in cyanobacteria species abundance and biomass were measured along with potential regulating environmental factors. Photosynthesis and $\mathrm{N}_{2}$-fixation rates were quantified as a function of irradiance levels in laboratory experiments, and the responses of the assemblage to the light-mediated differences in $\mathrm{pH}, \mathrm{DO}$ and DIC concentrations were analyzed.

\section{MATERIALS AND METHODS}

\section{Sampling and in situ measurements}

Water samples were collected in the upper Sassafras River for $\mathrm{N}_{2}$ - and C-fixation measurements weekly or biweekly from May to September 2010 at 2 adjacent areas, Budd's Landing (BL, 39.3723 ${ }^{\circ} \mathrm{N}, 75$. $\left.8399^{\circ} \mathrm{W}\right)$ and Drawbridge (DB, $\left.39.3641^{\circ} \mathrm{N}, 75.8820^{\circ} \mathrm{W}\right)$ (see Table 1). BL is located near the head of the river, and DB is further downriver close to a marina in Georgetown, Maryland (Fig. 1).

Photosynthetically active radiation (PAR) was measured at depth intervals of $0.2 \mathrm{~m}$ using a Li-Cor underwater PAR light sensor (Li-192). The vertical changes of temperature, $\mathrm{pH}, \mathrm{DO}$, and salinity were measured at the surface $(\sim 0.2 \mathrm{~m})$, middle $(\sim 0.5 \mathrm{~m})$,

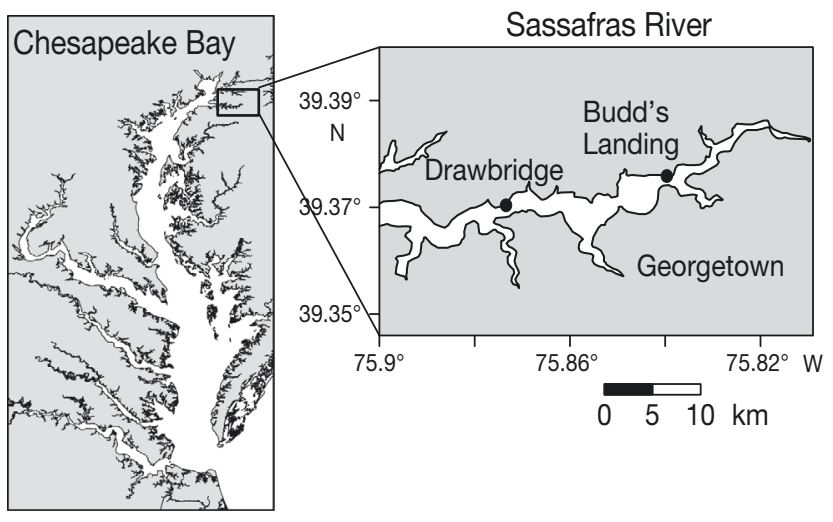

Fig. 1. Sampling stations in the upper Sassafras River, Maryland, USA. Budd's Landing (BL) and Drawbridge (DB) are located on the upper river, with BL close to the river head and DB slightly downstream from BL 
and bottom (1.0 to $2.0 \mathrm{~m}$ ) of the water column with a YSI sensor (XLM 600). Continuous monitoring for temperature, pH, DO, and salinity occurred every 15 min at BL using a YSI 6600 data logger, which was installed at $1 \mathrm{~m}$ depth by the Maryland Department of Natural Resource (MD DNR, reported at www. eyesonthebay.net).

\section{Experimental design}

Laboratory experiments were designed to examine the seasonal changes of $\mathrm{C}$ - and $\mathrm{N}_{2}$-fixation rates in response to environmental and self-regulated factors. After acclimation in uniform light for $\sim 2 \mathrm{~h}$ in a temperature-controlled chamber with gentle mixing, $75 \mathrm{ml}$ of each water sample was dispensed into $125 \mathrm{ml}$ glass serum bottles, with gas-tight suba-seal or crimp-seal stoppers. Irradiances ranging from 0 to $250 \mu \mathrm{mol}$ photons $\mathrm{m}^{-2} \mathrm{~s}^{-1}$ were used to generate different $\mathrm{pH}, \mathrm{DO}$, and DIC concentrations in the water samples based on the assumption that carbon removal and oxygen production rates change with light availability (Ploug 2008). Because water samples were delivered in the afternoon to Horn Point Laboratory, the incubations were started in the evening to keep their natural diel cycles. All bottles were incubated in a $10 \mathrm{~h}$ dark: $14 \mathrm{~h}$ light cycle at $25^{\circ} \mathrm{C}$, close to the average summer temperature. Samples for $\mathrm{N}_{2}$ fixation rates were incubated in triplicate bottles. Rates of primary production $\left(\mathrm{H}^{14} \mathrm{CO}_{3}{ }^{-}\right.$fixation) were measured in duplicate. Before and after the $24 \mathrm{~h}$ incubations, values of $\mathrm{pH}$ were measured immediately, and subsamples for dissolved inorganic nutrients, DO, and DIC were collected in triplicate. The second time point samples were taken from the $\mathrm{N}_{2}$ fixation bottles rather than those for $\mathrm{C}$ fixation to avoid ${ }^{14} \mathrm{C}$ contamination.

\section{$\mathbf{N}_{2}$-fixation and photosynthesis rate measurements}

$\mathrm{N}_{2}$-fixation rates were measured for $24 \mathrm{~h}$ on a light:dark cycle using the acetylene reduction assay (Capone 1995). Experiments were initiated with the injection of $1 \mathrm{ml}$ (10\% gas phase volume) acetylene $\left(\mathrm{C}_{2} \mathrm{H}_{2}\right)$, generated by reacting calcium carbide with distilled water, into the headspace of each bottle. Except for the preliminary experiments to choose the range of irradiance, sample bottles were incubated in the dark and at 2 light irradiances levels (125 and 250 umol photons $\mathrm{m}^{-2} \mathrm{~s}^{-1}$ ) on a $10 \mathrm{~h}$ dark:14 h light cycle. Gas phase subsamples $(100 \mu \mathrm{l})$ were taken from the headspace every $4 \mathrm{~h}$ during $24 \mathrm{~h}$ incubation and analyzed for ethylene gas, which is produced preferentially by the enzyme nitrogenase through the reduction of acetylene rather than the reduction of nitrogen to ammonium in this substrate analog assay. Ethylene samples were analyzed using a flame ionization detector (FID) on a Shimadzu gas chromatograph (GC-8A). The production of ethylene was corrected using the Bunsen gas solubility coefficient (Breitbarth et al. 2004), and then ethylene production was converted to $\mathrm{N}_{2}$ fixation using a theoretical ratio of 4:1 (Capone 1995).

In parallel with the estimations of $\mathrm{N}_{2}$-fixation rates, photosynthesis under similar experimental conditions was also measured. After adding $30 \mu \mathrm{l} \mathrm{NaH}{ }^{14} \mathrm{CO}_{3}$ standard solution $\left(10.5 \mu \mathrm{Ci} 100 \mathrm{ll}^{-1}\right)$ into the sample bottles, C-fixation rates were measured at irradiances of $0,62.5,125$, and $250 \mu \mathrm{mol}$ photons $\mathrm{m}^{-2} \mathrm{~s}^{-1}$ (Parsons et al. 1984). Samples were incubated for $24 \mathrm{~h}$ to estimate net daily photosynthesis. The water samples were filtered on GF/F filters, washed with deionized water, dried overnight after adding a drop of $\mathrm{HCl}$, and then placed into a scintillation vial containing $10 \mathrm{ml}$ of scintillation fluid (Ecoscint). All Cfixation rates were calculated using the initial DIC concentrations. Distilled water was used in control bottles and processed separately for $\mathrm{C}$ - and $\mathrm{N}_{2}$ fixation measurements.

\section{Chlorophyll a, nutrients, and phytoplankton}

Water samples for chlorophyll a (chl a) were filtered on Whatman glass fiber filters (GF/F) in triplicate and frozen in the dark. Samples for particulate C, N, and P were filtered onto pre-combusted (450 ${ }^{\circ} \mathrm{C}, 4 \mathrm{~h}$ ) GF/F filters. Subsamples for soluble reactive phosphorus (SRP) and dissolved inorganic nitrogen (DIN, including $\mathrm{NO}_{3}{ }^{-}, \mathrm{NO}_{2}{ }^{-}$, and $\mathrm{NH}_{4}{ }^{+}$) were filtered through $0.45 \mu \mathrm{m}$ cellulose acetate syringe filters and frozen until analyzed. Samples for cell counting were preserved with $2.5 \%$ glutaraldehyde and filtered on $0.2 \mu \mathrm{m}$ polycarbonate filters.

\section{DO, DIC and pH in laboratory incubations}

Samples for DO and DIC were siphoned into $10 \mathrm{ml}$ air-tight tubes, with $\mathrm{HgCl}_{2}$ addition to a final concentration of $10 \mathrm{mg} \mathrm{l}^{-1}$ to inhibit microbial activity (Kana et al. 1994); the glass tubes were stored under water at incubation temperature until analysis. The $\mathrm{pH}$ of samples was measured using a standard calibrated 
Radiometer glass $\mathrm{pH}$ electrode (sensitivity 0.01). On several occasions, water samples were dispensed into the 11 air-tight bottles, leaving 2/5 headspace beyond the water surface. Changes in $\mathrm{pH}$ and DO at each irradiance were monitored continuously using $\mathrm{pH}$ and DO microsensors (NexSens Technology) installed through the top of these bottles and immersed into the water. Samples of DIC and DO were collected from $\mathrm{N}_{2}$-fixation incubators, and compared with results from microsensors and chemical analysis.

\section{Cell density and biomass}

Cells were counted using epi-fluorescence microscopy (Ex 465-495, DM 505 and BA 515-555; Guillard \& Sieracki 2005). Because of differences in cell size among species, we used biomass to characterize changes in phytoplankton community composition. Based on cyanobacteria identification (Gronberg \& Annadotter 2006) and geometric approximations (Hillebrand et al. 1999), biomass was calculated using a regression model for 1 to $1000 \mu^{3}$ cells preserved in glutaraldehyde (Verity et al. 1992):

$$
\log \mathrm{C}=-0.363+0.863 \times \log \mathrm{BV}
$$

where BV and $\mathrm{C}$ are biovolume $\left(\mu^{3} \mathrm{cell}^{-1}\right)$ and carbon content of biomass (pg cell ${ }^{-1}$ ), respectively.

\section{Chemical analysis}

Subsamples for chl a were extracted with $90 \%$ acetone overnight, and determined with a 10-AU-005CE fluorometer (Parsons et al. 1984). Concentrations of SRP and $\mathrm{NH}_{4}{ }^{+}$were measured colorimetrically (Parsons et al. 1984). Both $\mathrm{NO}_{3}{ }^{-}$and $\mathrm{NO}_{2}{ }^{-}$were analyzed using ion chromatography. The analysis of particulate organic $\mathrm{C}$ and $\mathrm{N}$ were conducted by the University of Maryland Center for Environmental Science, Horn Point Laboratory Analytical Services using a CE-440 Elemental Analyzer (Exeter Analytical). Particulate organic $\mathrm{P}$ was analyzed according to the protocol of Parsons et al. (1984). DO concentrations were determined with the $\mathrm{O}_{2}$ :Ar method using membrane inlet mass spectrometry analysis (MIMS), calibrated with equilibrium water at incubation temperature and ambient salinities (Kana et al. 1994). To measure total concentrations of dissolved carbon $\left(\mathrm{CO}_{2}, \mathrm{HCO}_{3}{ }^{-}\right.$, and $\left.\mathrm{HCO}_{3}\right)$, samples for DIC were preacidified with the automatically refilled $\mathrm{H}_{3} \mathrm{PO}_{4}$ solution and followed with infrared radiation analysis (Apollo Scitech Model A5-C3).

\section{Statistical analysis}

The effects of light on $\mathrm{C}$ - and $\mathrm{N}_{2}$-fixation rates were assessed with a nested ANOVA at the level of sampling time for $\mathrm{BL}$ and $\mathrm{DB}$. Linear regressions were used to quantify the influence of irradiance on rates of $\mathrm{C}$ and $\mathrm{N}_{2}$ fixation, as well as the influence of photosynthesis on $\mathrm{N}_{2}$ fixation. A Pearson correlation was used to examine co-variation of $\mathrm{pH}, \mathrm{DO}$, and DIC with irradiance during incubations. A forward stepwise regression was used to analyze the effects of nutrients, irradiance, $\mathrm{pH}, \mathrm{DIC}$, and DO on photosynthesis and $\mathrm{N}_{2}$-fixation rates for samples spanning the whole bloom season. All data analyses were conducted with SAS system for windows (9.0) (Delwiche \& Slaughter 2003). At the beginning and end of incubations, the concentrations of available carbon source $\left(\mathrm{CO}_{2}\right.$ and $\left.\mathrm{HCO}_{3}{ }^{-}\right)$for cyanobacteria were calculated from DIC and $\mathrm{pH}$ using the package AquaEnv of R software, which is suitable for application to oligohaline waters (Hofmann et al. 2010).

\section{RESULTS}

\section{In situ conditions}

The upper Sassafras River is a shallow ( 2 m), turbid, tidal freshwater sub-estuary of Chesapeake Bay. Water temperature increased from spring to summer and declined gradually after September, with the MD DNR continuous monitoring values similar to our field observations (Fig. 2). Within the period that $\mathrm{N}_{2}$ fixation was detectable, average water temperatures were $25.9 \pm 2.1^{\circ} \mathrm{C}$, close to our incubation setup. Salinity increased slightly from the upper river site (BL) to the downstream site (DB). Salinity showed a clear seasonal pattern that decreased from 0.4 to 1.5 in May to below 0.2 in summer and then increased up to 1.8 after late August. Cyanobacteria were not concentrated in or near surface layers but were relatively uniformly distributed in the water column. PAR reduced dramatically from $\sim 1000 \mu \mathrm{mol}$ photons $\mathrm{m}^{-2}$ $\mathrm{s}^{-1}$ at the surface to zero at the bottom (Fig. 3). Although PAR varied at the surface, our irradiance of $250 \mu \mathrm{mol}$ photons $\mathrm{m}^{-2} \mathrm{~s}^{-1}$ was close to PAR at the 0 to $0.5 \mathrm{~m}$ horizontal layer; our irradiances of 62.5 and 125 $\mu$ mol photons $\mathrm{m}^{-2} \mathrm{~s}^{-1}$ were often found between 0.5 and $1.0 \mathrm{~m}$ depth, and the dark incubation was representative of the bottom water $(0.2$ to $0.5 \mathrm{~m}$ above sediment). The light attenuation coefficient $\left(K_{\mathrm{d}}\right)$, estimated from the light flux at different depths, ranged from 3.0 to $5.8 \mathrm{~m}^{-1}$, approaching a maximum value during the peak of the bloom at the BL site. 
a) Continuous monitoring

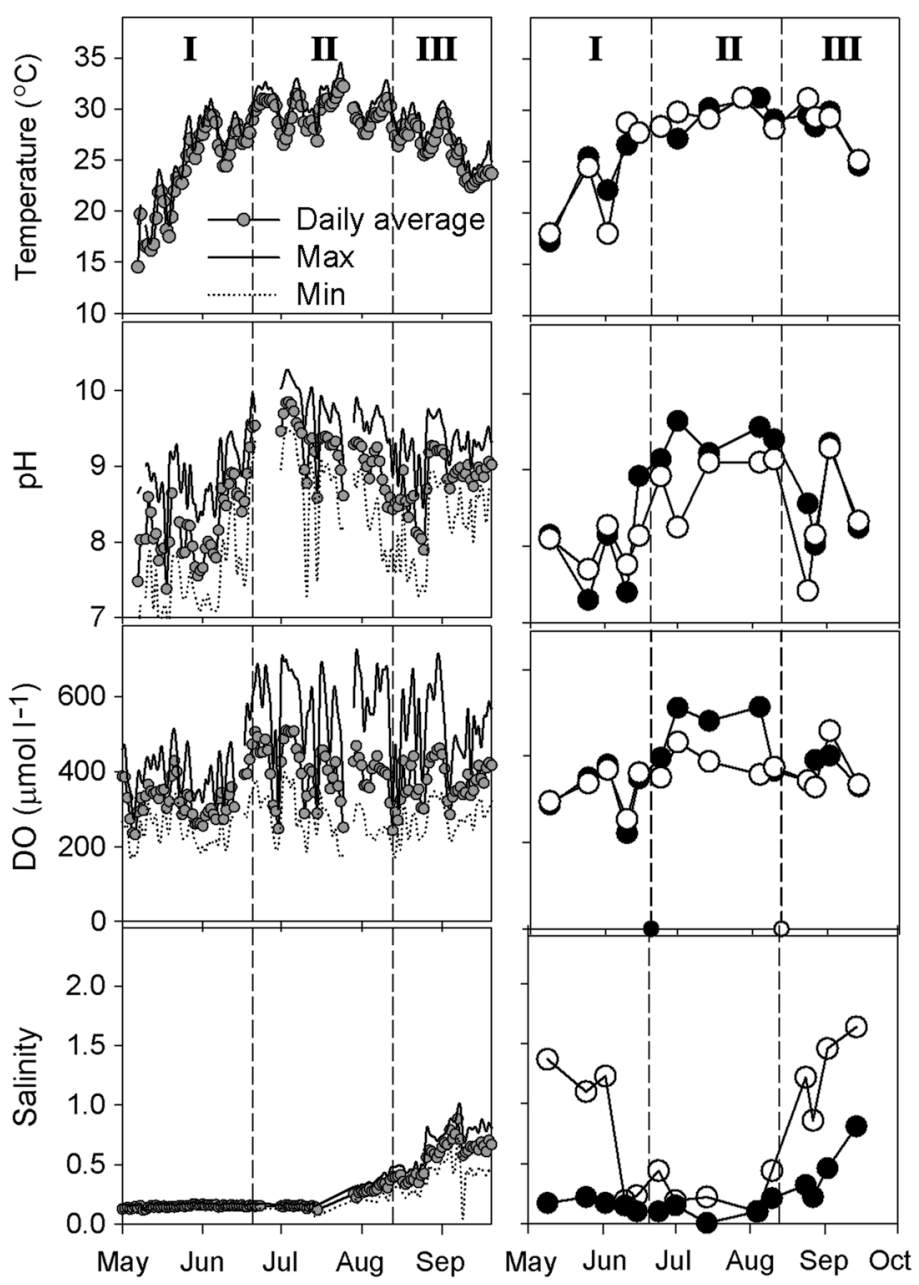

Fig. 2. Seasonal patterns of temperature, $\mathrm{pH}$, dissolved oxygen (DO) and salinity. (a) Continuous changes at Budd's Landing. Circles represent the daily average of the continuous records. Daily maximum and minimum values are indicated with solid and dotted lines, respectively (Maryland Department of Natural Resources). (b) In situ measurements at both Budd's Landing (solid dark circles) and Drawbridge (empty white circles). Data are shown for bloom Stages I, II, and III

\section{Bloom development and succession}

Over 20 cyanobacteria species were observed during summer 2010, with the dominant cyanobacteria varying over time. The most abundant of the non- $\mathrm{N}_{2}$ fixing cyanobacteria were Microcystis spp. (M. aeruginosa, M. wesenbergii, and M. botrys) and Merismopedia spp. (e.g. M. glauca). Based on morphology, several groups of diazotrophic cyanobacteria were found including: filamentous heterocystous Anabaena spp., such as $A$. circinalis, A. planctonica, $A$. Oscillarioides, A. spiroides, and A. flos-aquae; non- a) Precipitation

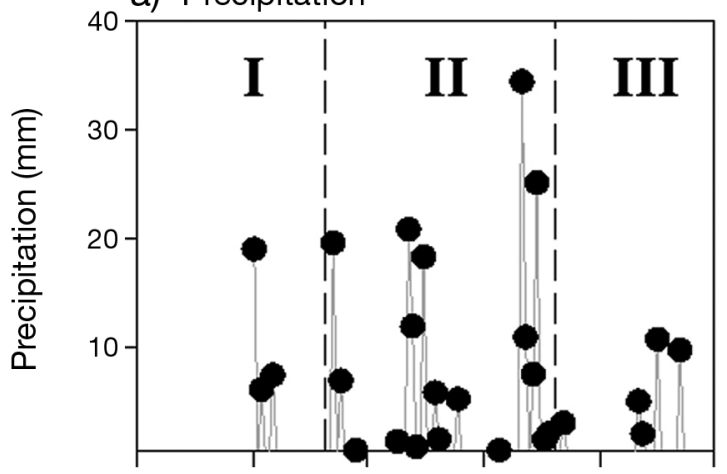

b) $\mathrm{Chl} \mathrm{a}$

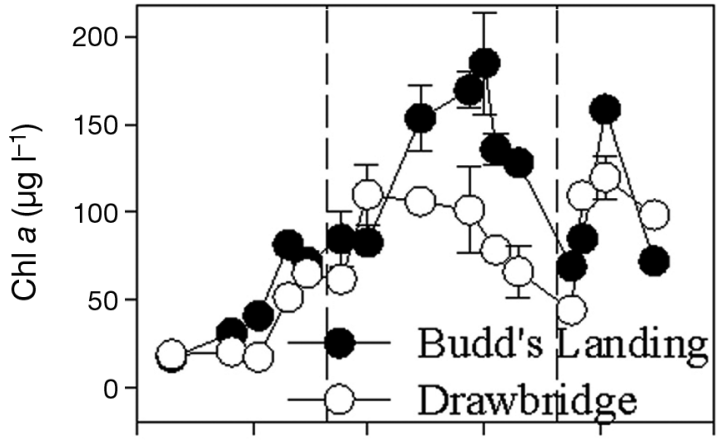

c) PAR
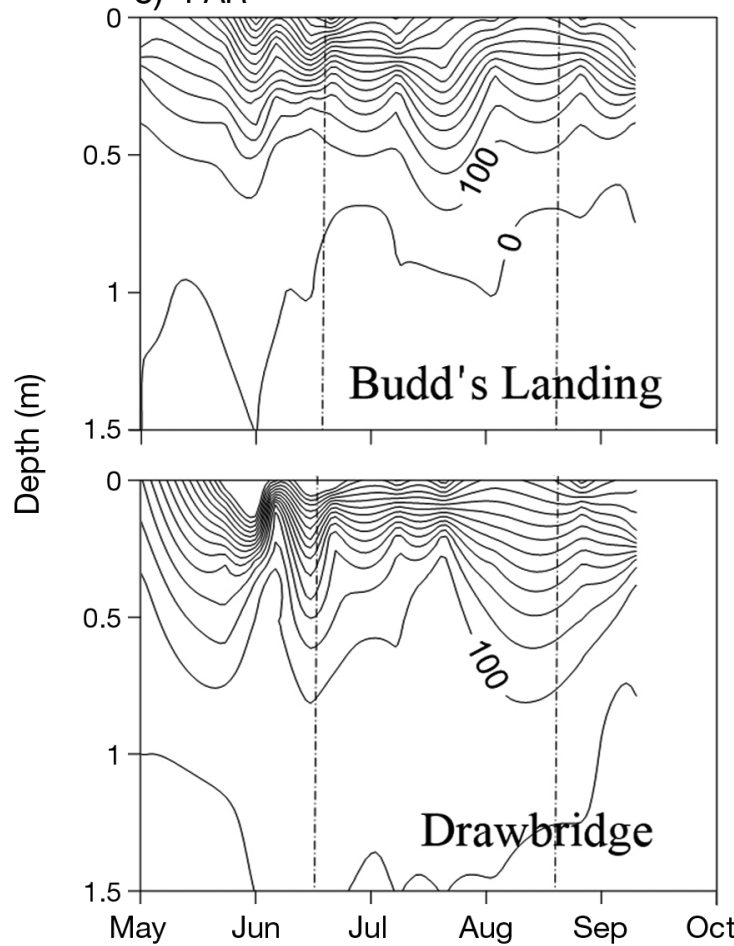

Fig. 3. Seasonal variation in (a) precipitation, (b) chlorophyll a concentrations $( \pm \mathrm{SE})$ and (c) vertical profiles of photosynthetically available radiation (PAR) from early May to mid-September in 2010. Precipitation data at Georgetown, Maryland were obtained from weather.com. Chlorophyll $a$ and PAR were measured at Budd's Landing and Drawbridge.

Data are shown for bloom Stages I, II, and III 
Table 1. The total cyanobacterial concentration $\left(\log _{10}\right.$ cells $\mathrm{ml}^{-1}$ ) at Budd's Landing (BL) and Drawbridge (DB) from May to September 2010. The average standard error is $<2 \%$ of cell concentration

\begin{tabular}{|c|c|c|c|}
\hline \multirow[t]{2}{*}{ Phase } & \multirow[t]{2}{*}{ Date } & \multicolumn{2}{|c|}{ Cyanobacteria concentration } \\
\hline & & BL & DB \\
\hline \multirow[t]{5}{*}{ Stage I } & 10 May $^{\mathrm{a}}$ & 0.12 & 0.24 \\
\hline & 24 May $^{\mathrm{a}}$ & 5.11 & 4.38 \\
\hline & 10 June $^{\mathrm{b}}$ & 5.41 & 5.36 \\
\hline & 15 June $^{\mathrm{b}}$ & 5.62 & 6.15 \\
\hline & 24 June & 6.08 & 5.57 \\
\hline \multirow[t]{3}{*}{ Stage II } & 30 June & 5.92 & 5.86 \\
\hline & 16 July $^{\mathrm{b}}$ & 6.22 & 6.10 \\
\hline & 10 August $^{\mathrm{b}}$ & 5.98 & 4.17 \\
\hline \multirow[t]{3}{*}{ Stage III } & 24 August & 6.57 & 5.53 \\
\hline & 2 September & 6.96 & 6.60 \\
\hline & 15 September $^{b}$ & 5.92 & 6.17 \\
\hline \multicolumn{4}{|c|}{$\begin{array}{l}\text { although } \mathrm{N}_{2} \text {-fixation rates were measured at each sam } \\
\text { pling time, } \mathrm{N}_{2} \text { fixation was undetectable on May } 10 \text { an } \\
\text { May } 24\end{array}$} \\
\hline \multicolumn{4}{|c|}{${ }^{\mathrm{b}}$ Sample date for carbon fixation } \\
\hline
\end{tabular}

heterocystous Pseudanabaena sp. and Lyngbya sp.; unicellular Synechocystis sp. and Chroococcus spp.

Field observations of cell densities (Table 1), DO and $\mathrm{pH}$ (Fig. 2), chl a (Fig. 3), and biomass of phytoplankton (Fig. 4) were all indicative of cyanobacterial bloom development. The bloom period can be divided into 3 periods: Stage I (the bloom initiation period, May to mid-June), Stage II (first bloom, from midJune to mid-August), and Stage III (second bloom, after late August) (Fig. 3b).

In Stage I, the cyanobacteria bloom was initiated with rising temperature, and led to the sharp increases in cell concentration, chl $a, \mathrm{pH}$, and DO from May to early June. The cyanobacteria population increased more than 10 -fold at the BL and DB sites (Table 1). Although diel changes in irradiance led to daytime increases and nighttime decreases, the average daily $\mathrm{pH}$ from the real-time records were similar to the discrete in situ observations at BL (Fig. 2) and the laboratory analysis using a $\mathrm{pH}$ probe (Fig. 5). The $\mathrm{pH}$ in the field gradually rose from 7 to 9 at both stations. The diel fluctuation in DO was large but the daily average DO was relatively constant at 300 to $400 \mu \mathrm{mol} \mathrm{l}^{-1}$ (Fig. 2), which was close to our field observations and laboratory incubations. The change in chl a concentrations was similar at both sites, increasing rapidly from $\sim 20 \mu \mathrm{g} \mathrm{l}^{-1}$ to $\sim 80 \mu \mathrm{g} \mathrm{l^{-1 }}$ (Fig. 3). The dominant phytoplankton shifted from eukaryotes and non- $\mathrm{N}_{2}$-fixing cyanobacteria, Microcystis spp. and Merismopedia spp., to heterocystous $\mathrm{N}_{2}$-fixers Anabaena spp. (Fig. 4). The biomass of non$\mathrm{N}_{2}$ fixers increased slightly (less than $\sim 1 \mathrm{mg} \mathrm{C}^{-1}$ ) at both stations. Biomass of Anabaena spp. increased dramatically to $7 \mathrm{mg} \mathrm{Cl}^{-1}$ at BL and $4 \mathrm{mg} \mathrm{Cl}^{-1}$ at DB. Anabaena spp. grew from a small fraction (12 to $24 \%$ ) of the total phytoplankton biomass in May to $\sim 95 \%$ at BL and over $60 \%$ at DB by the end of Stage I.

In Stage II, the cyanobacteria bloom fully developed at the river head and gradually declined towards the downstream site. At the upriver station BL, chl a peaked at $\sim 180 \mu g \mathrm{l}^{-1}$ in August (Fig. 3), with cyanobacteria abundance (Table 1) and biomass (Fig. 4) reaching to maximum values. The $\mathrm{pH}$ increased dramatically to 10.5 , with the daily average $\mathrm{pH}$ sustained above 9.2 for several weeks (Fig. 2). Meanwhile, the daily average DO almost doubled after entering Stage II and reached the maximum of $773 \mathrm{\mu mol} \mathrm{l}^{-1}$. During the same period, bloom-mediated changes (chl $a, \mathrm{pH}$, and DO) at the downstream station (DB) were lower than observations at the river head site (BL) (Figs. 2b \& 3b), with the highest value occurring in early July and dissipating in August. The cyanobacteria community at both of the study
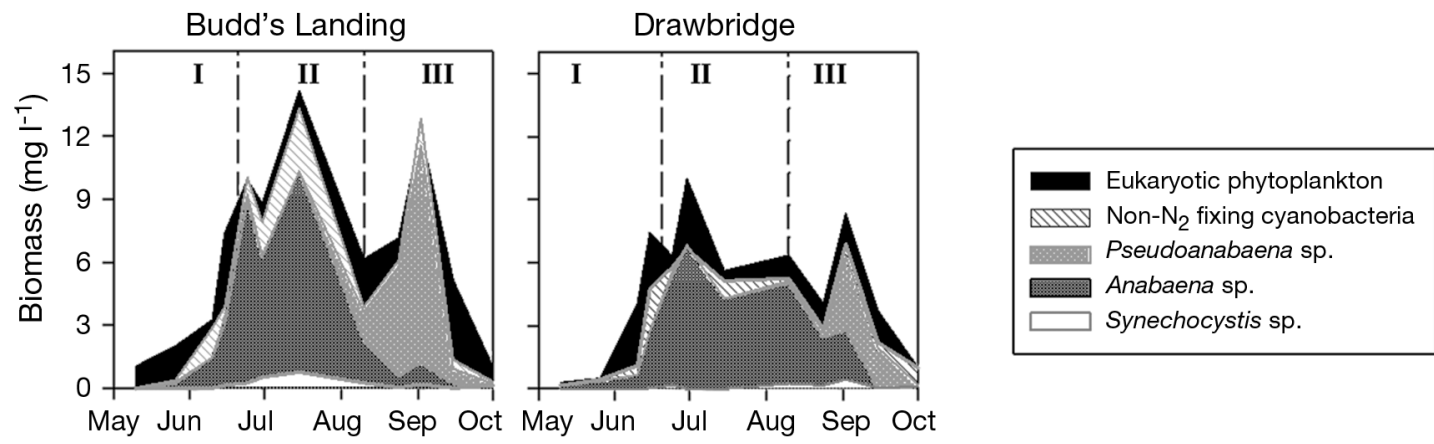

Fig. 4. Estimated biomass of phytoplankton at Budd's Landing and Drawbridge in 2010, including non-diazotrophic cyanobacteria (mostly Microcystis spp.), diazotrophic cyanobacteria (heterocystous Anabaena spp., unicellular Synechocystis sp. and Chroococcus spp.; filamentous non-heterocystous Pseudoanabaena sp.), and eukaryotic phytoplankton. Data are shown for bloom Stages I, II, and III 

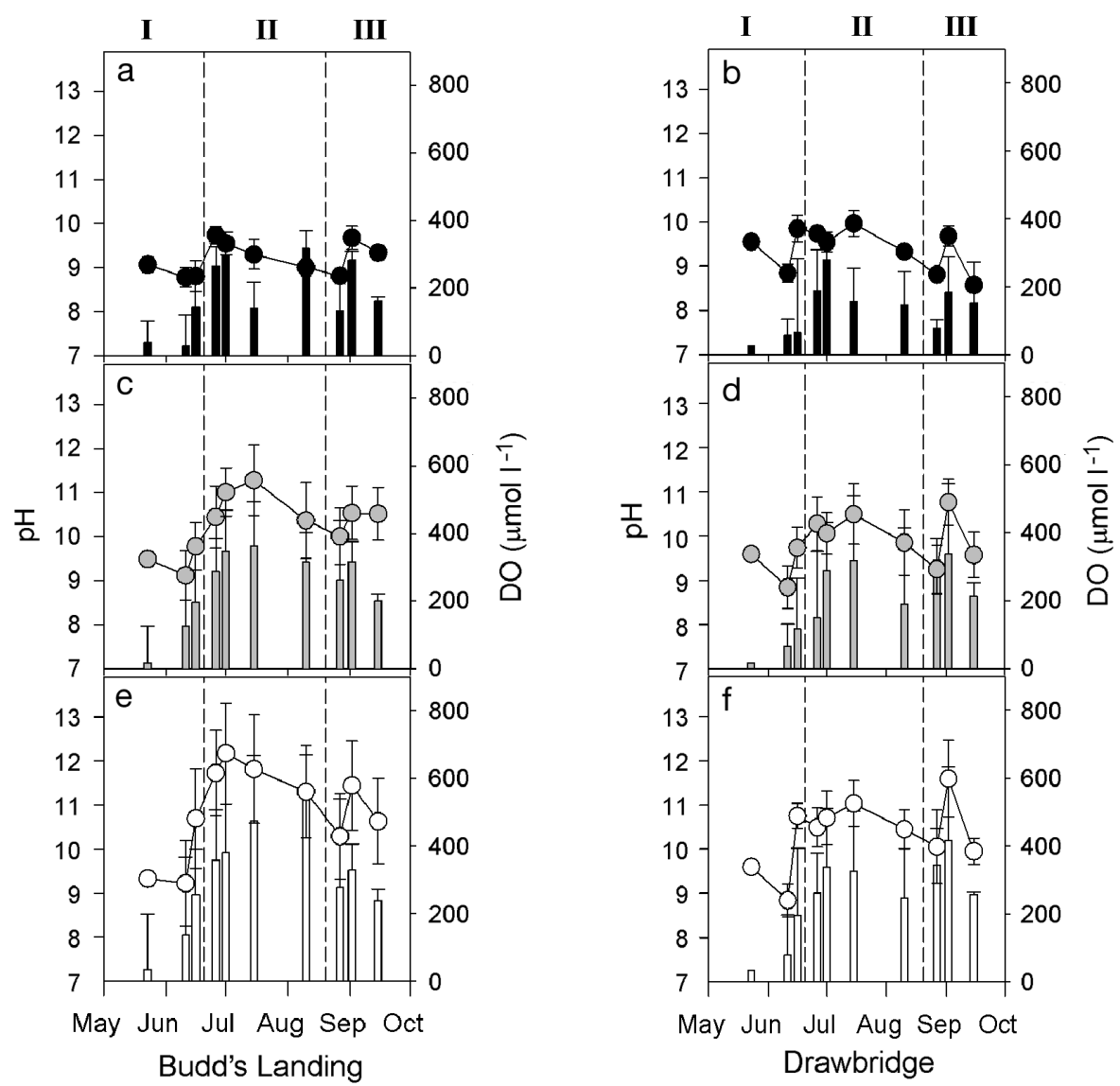

Fig. 5. Average $\mathrm{pH}$ and dissolved oxygen (DO) in the laboratory incubations in (a,b) the dark and at 2 light irradiances levels - (c,d) 125 and (e,f) $250 \mu \mathrm{mol}$ photons $\mathrm{m}^{-2} \mathrm{~s}^{-1}$ —of samples from Budd's Landing and Drawbridge. The bars are $\mathrm{pH} \pm \mathrm{SE}$; the circles are DO $\pm \mathrm{SE}$. Data are shown for bloom Stages I, II, and III

sites became dominated by diazotrophs, such as Anabaena spp., Synechocystis sp., and Chroococcus spp. (Fig. 4), with the biomass of $\mathrm{N}_{2}$-fixers Anabaena spp. peaking in July, and reaching $10.5 \mathrm{mg} \mathrm{C} \mathrm{l}^{-1}$

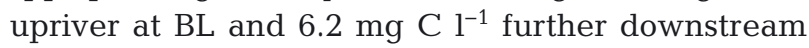
(DB). The biomass of the unicellular $\mathrm{N}_{2}$ fixers, Synechocystis sp. and Chroococcus spp., was relatively low but constant $\left(<0.8 \mathrm{mg} \mathrm{Cl}^{-1}\right)$ from July to August.

The second cyanobacteria bloom (Stage III) occurred after heavy precipitation from August 13 to 17 (Fig. 3a). The bloom developed quickly, with the peak of cell abundance and chl $a$ in early September (Table 1, Fig. 3b). The non-heterocystous filamentous $\mathrm{N}_{2}$-fixer Pseudanabaena sp., together with a small fraction of Synechocystis sp. and Chroococcus spp., comprised up to $94 \%$ and $42.2 \%$ of the total phytoplankton biomass at BL and DB, respectively (Fig. 4). Although the peak cell concentration was higher during Stage III than our observations during Stage II (Table 1), the highest concentrations of chl a were close to or less than the values in Stage II, which

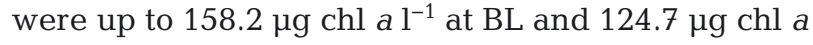

$1^{-1}$ at DB (Fig. 3). This may be due to the fact that the small diazotrophic Pseudanabaena sp. (average BV: $19.89 \mathrm{\mu m}^{3} \mathrm{cell}^{-1}$ ) became prevalent after the decline of Anabaena spp. (BV ranging from 81 to $1192 \mu^{3}$ cell $^{-1}$ ). The estimated biomass of Pseudanabaena sp. was $5.72 \mathrm{pg} \mathrm{C}$ cell $^{-1}, 2.6$ to $27.4 \%$ of biomass per cell of Anabaena spp. The $\mathrm{N}_{2}$-fixer Pseudanabaena sp. reached a maximum of $12 \mathrm{mg} \mathrm{Cl}^{-1}$ at $\mathrm{BL}$, approximately twice its biomass at DB (Fig. 4). At the end of September, a slight increase in salinity and decrease in water temperature were observed at both sites (Fig. 2). Coincidently, the bloom rapidly dissipated (Figs. 3 \& 4), accompanied by sharp decreases in $\mathrm{pH}$ and DO in the upper Sassafras River (Figs. $2 \& 5$ ).

\section{Dissolved inorganic nutrients and particulate $\mathrm{C}, \mathrm{N}$, and $\mathrm{P}$}

The concentrations of dissolved inorganic nutrients decreased with bloom development from spring to summer (Fig. 6). The sharp decline in $\mathrm{NO}_{3}{ }^{-}$concen- 

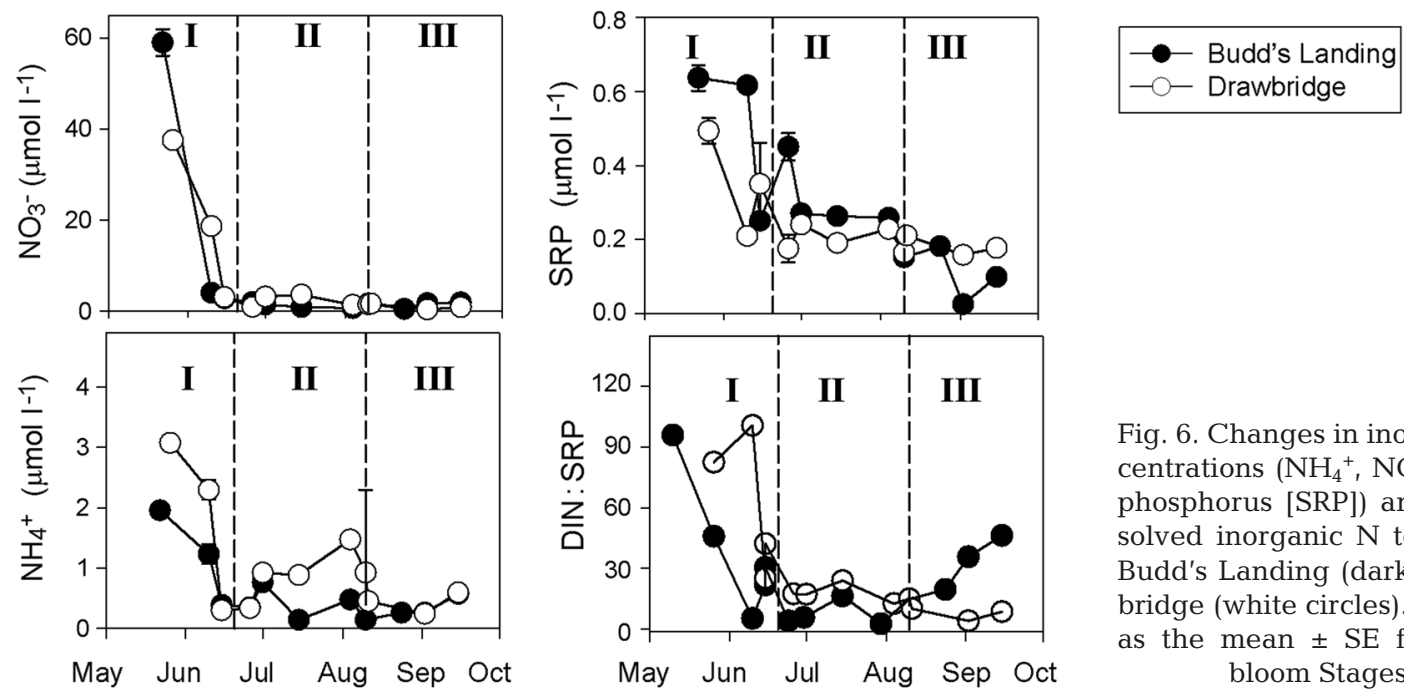

Fig. 6. Changes in inorganic nutrient concentrations $\left(\mathrm{NH}_{4}{ }^{+}, \mathrm{NO}_{3}{ }^{-}\right.$, soluble reactive phosphorus [SRP]) and the ratios of dissolved inorganic $\mathrm{N}$ to $\mathrm{SRP}$ (DIN:SRP) at Budd's Landing (dark circles) and Drawbridge (white circles). Data are presented as the mean $\pm \mathrm{SE}$ for nutrients during bloom Stages I, II, and III

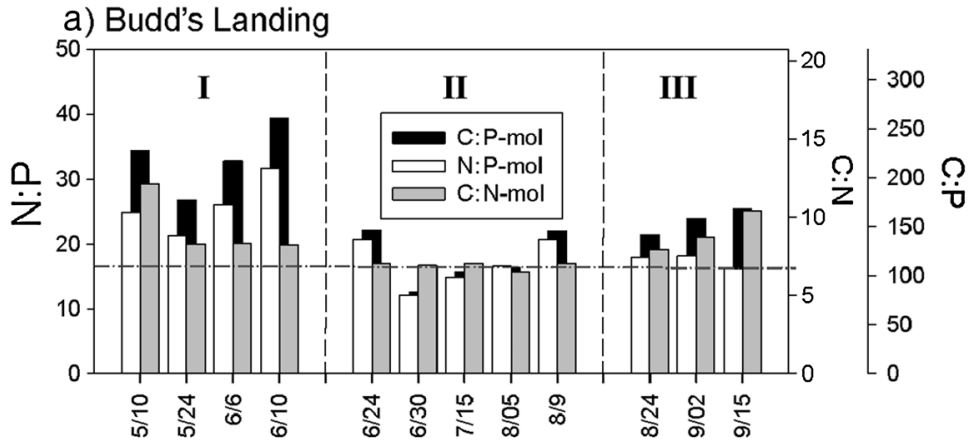

b) Drawbridge

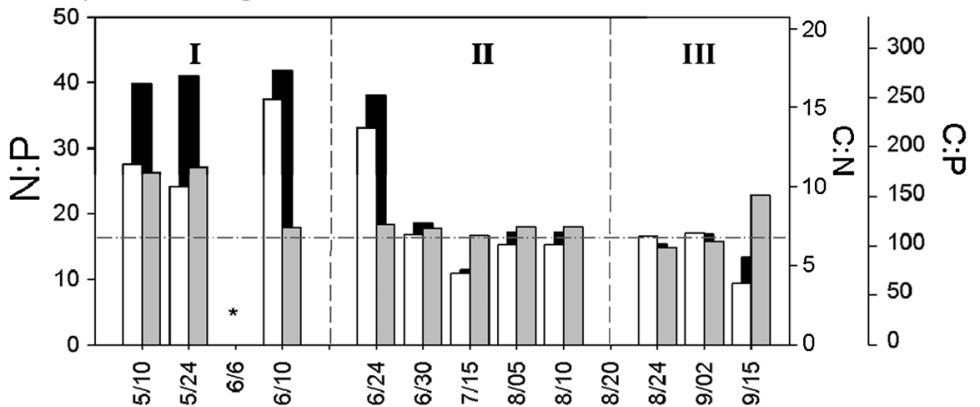

Fig. 7. Particulate molar ratio of C:N:P at Budd's Landing and Drawbridge. $\left({ }^{*}\right)$ missing data. Horizontal dot-dashed line $=$ Redfield ratio.

Data are shown for bloom Stages I, II, and III; dates given as mo/d

initiation in May, the ratios of DIN:SRP declined from $>100$ to $\sim 3$, which remained below the Redfield Ratio most of the summer at the upper river site (BL). At the end of the bloom season, an abrupt increase in DIN:SRP (>40) occurred in September at BL (Fig. 6). At the downstream site (DB), N:P ratios demonstrated a similar declining trend with relatively higher values than those observations in the upper river (BL).

The ratio of $\mathrm{C}: \mathrm{N}, \mathrm{N}: \mathrm{P}$, and $\mathrm{C}: \mathrm{P}$ in particulate organic matter varied with time and location (Fig. 7). At the upriver station $\mathrm{BL}$, the ratios ranged from 6 to 12 for $\mathrm{C}: \mathrm{N}$, from 18 to 32 for N:P, and from 84 to 265 for C:P. With bloom development, the ratios of $\mathrm{C}: \mathrm{N}$ decreased from stage I $(>12)$ to the high $\mathrm{pH}$ and DO periods in Stages II and III (below or close to 6.6, the Redfield ratio). In response to the reduction of DIN:SRP in water and the dominance of $\mathrm{N}_{2}$-fixing cyanobacteria, ratios of $\mathrm{N}: \mathrm{P}$ in particulate organic matter decreased from 20 to 32 in Stage I to $\leq 16$ in Stages II and III. Ratios of C:P were generally higher than the Redfield ratio during bloom Stage I when bioavailable $\mathrm{P}$ was limited in the water, and

trations occurred at both sites in the Sassafras River, decreasing from $>40 \mu \mathrm{mol} \mathrm{l}^{-1}$ in May to $<1.2 \mu \mathrm{mol} \mathrm{l}^{-1}$ in June and remained low (sometimes below detection limit) the whole summer. Concentrations of $\mathrm{NH}_{4}{ }^{+}$ exhibited similar patterns, although they were generally lower at the riverhead than downstream. SRP concentrations at both stations decreased from 0.5 to $\sim 0.6 \mu \mathrm{mol} \mathrm{l}^{-1}$ to 0.03 to $\sim 0.2 \mu \mathrm{mol} \mathrm{l^{-1 }}$. After the bloom then reduced to less than or near to the Redfield ratio during bloom Stage II. At DB, the patterns of C:P and $\mathrm{N}$ :P were similar, declining from $>250$ and 25 to 38 , respectively, in Stage I to at or below the Redfield ratio in Stages II and III. The ratios of C:N remained lower ( 6.6) at higher $\mathrm{pH}$ and DO periods than bloom initiation (>10) and dissipation ( 9.5) after September 10, 2010. 


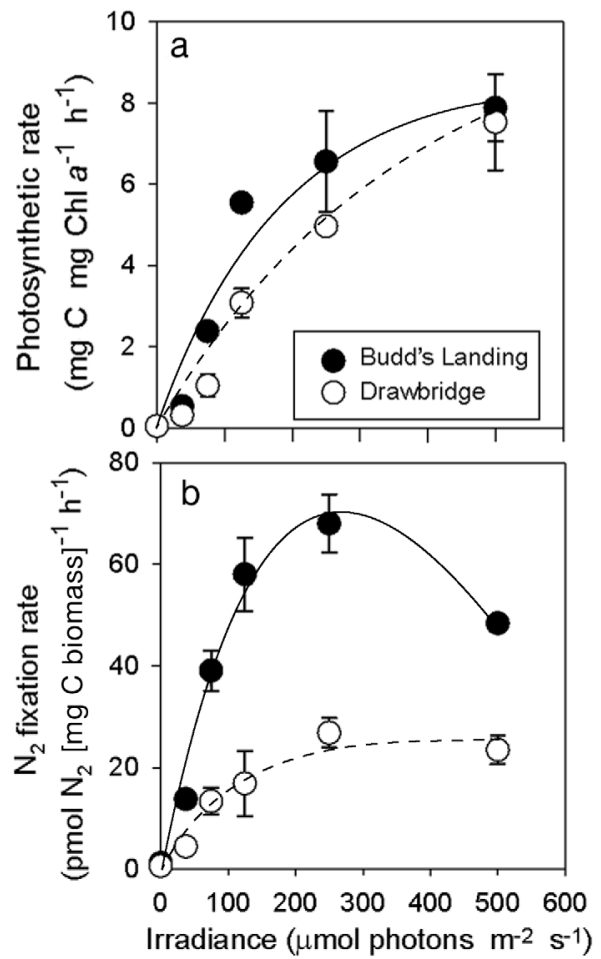

Fig. 8. Photosynthesis and $\mathrm{N}_{2}$-fixation rates as a function of irradiance in laboratory incubations of samples collected from Budd's Landing (dark circles) and Drawbridge (white circles) on June 10, 2010. The irradiance levels were 0, 31.5, $62.5,125,250$ and $500 \mu \mathrm{mol}$ photons $\mathrm{m}^{-2} \mathrm{~s}^{-1}$

\section{Photosynthesis}

A preliminary $4 \mathrm{~h}$ experiment was conducted to determine the irradiance range that was not inhibitory for subsequent experiments (Fig. 8). According to results at both stations, photoinhibition of $\mathrm{C}$ fixation was not observed at the irradiance range of 0 to $500 \mu \mathrm{mol}$ photons $\mathrm{m}^{-2}$ $\mathrm{s}^{-1}$. However, $\mathrm{N}_{2}$ fixation was constrained at irradiances above $250 \mu \mathrm{mol}$ photons $\mathrm{m}^{-2} \mathrm{~s}^{-1}$. Irradiances $\leq 250 \mu \mathrm{mol}$ photons $\mathrm{m}^{-2} \mathrm{~s}^{-1}$, close to the average PAR of the top 0.5 to $1.0 \mathrm{~m}$ at the Sassafras River, were therefore used for subsequent incubations.

C-fixation rates, normalized with daily averages of chl $a$, were close to zero in the dark bottles and often positively related to irradiances. The chl a-normalized C-fixation rates at the same light level often decreased with a greater abundance of cyanobacteria, although photosynthesis rates (per volume) usually increased in the water samples (Fig. 9). The chl a-normalized C-fixation rates at $250 \mu \mathrm{mol}$ photons $\mathrm{m}^{-2}$ $\mathrm{h}^{-1}$ declined from 6.2 to $7.8 \mathrm{mg} \mathrm{C} \mathrm{mg} \mathrm{chl} a^{-1} \mathrm{~h}^{-1}$ in Stage I to $<2 \mathrm{mg} \mathrm{C} \mathrm{mg} \mathrm{chl} \mathrm{a}^{-1} \mathrm{~h}^{-1}$ in Stage II, and then rose to 2 to $4 \mathrm{mg} \mathrm{C} \mathrm{mg} \mathrm{chl} a^{-1} \mathrm{~h}^{-1}$ at the end of Stage III (Fig. 9). Moreover, photosynthetic efficiency $\left(\alpha^{\mathrm{CF}}\right)$, the linear regression coefficients of irradiance, and chl a-normalized $\mathrm{C}$-fixation rates changed with bloom development (Table 2). The estimated $\alpha^{\mathrm{CF}}$ decreased from Stage I to a minimum range of 1.6 to 8.3 mg C mg chl $a^{-1} \mathrm{~h}^{-1}$ ( $\mu \mathrm{mol}$ photons $\left.\mathrm{m}^{-2} \mathrm{~s}^{-1}\right)^{-1}$ in Stage II, and then rose again when the bloom dissipated (Table 2).

However, increases in irradiance had non-significant effects on net photosynthesis in 3 out of 4 incubations under the conditions of low DIC and elevated $\mathrm{pH}$ during the high biomass peaks in bloom Stage II (Table 2, Figs. 5 \& 9). Particularly, net C-uptake rates were low when available DIC (sum of $\mathrm{CO}_{2}$ and $\mathrm{HCO}_{3}{ }^{-}$) concentrations decreased, as the combined result of decreases in total DIC with high $\mathrm{pH}$ (9.3 to 11) (Fig. 10).

\section{Response of DO, pH, and DIC during laboratory incubations}

Photosynthetic C uptake and oxygen production

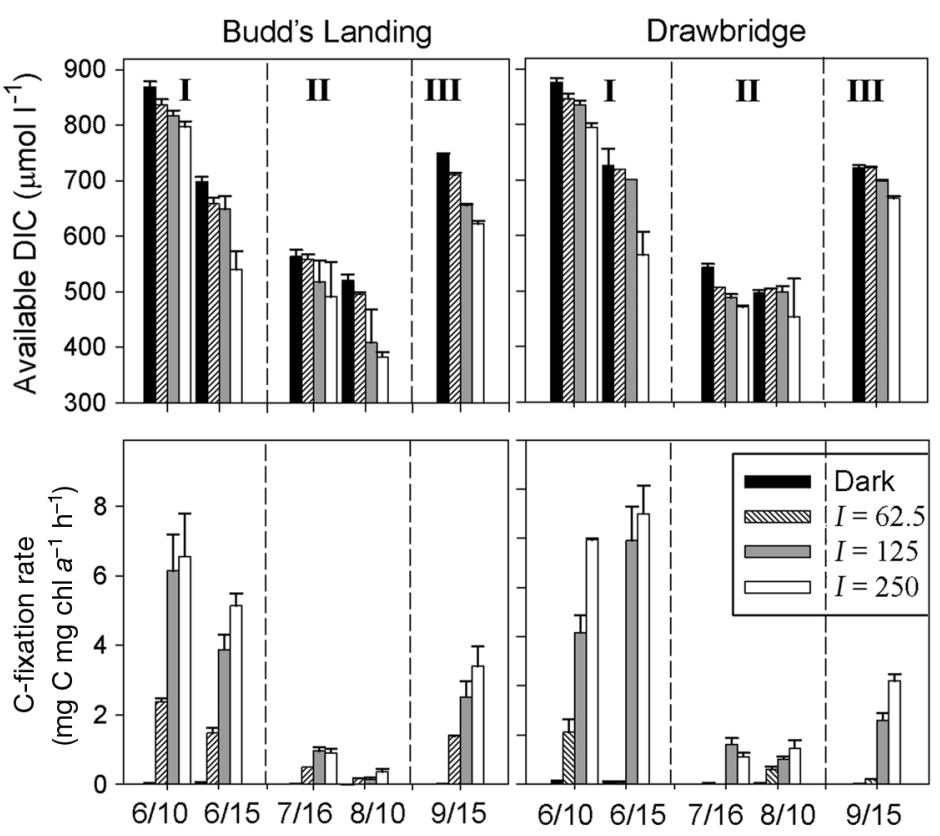

Fig. 9. Mean ( $\pm \mathrm{SD}$ ) of available dissolved inorganic carbon (DIC) concentration and C-fixation rates in laboratory incubations of samples from Budd's Landing and Drawbridge. Samples were taken during bloom Stage I (on June 10 and June 15), Stage II (on July 16 and August 10), and the end of bloom Stage III (on September 15). Available DIC concentrations were calculated from the equilibrium of total DIC and $\mathrm{pH}$ of samples collected before and after incubations at irradiances $(I)$ of $0,62.5,125$, and $250 \mu \mathrm{mol}$ photons $\mathrm{m}^{-2} \mathrm{~s}^{-1}$ 
Table 2. Response of $\mathrm{N}_{2}$ fixation and photosynthesis to irradiance in laboratory incubations of samples collected during bloom Stages I, II and III at Budd's Landing (BL) and Drawbridge (DB) on the upper Sassafras River. $\mathrm{N}_{2}$-fixation efficiency $\left(\alpha^{\mathrm{NF}}, \mathrm{mg} \mathrm{N} \mathrm{mg} \text { chl } a^{-1} \mathrm{~h}^{-1} \text { ( } \mu \text { mol photons } \mathrm{m}^{-2} \mathrm{~s}^{-1}\right)^{-1}$ ) and photosynthetic efficiency $\left(\alpha^{\mathrm{CF}}, \mathrm{mg} \mathrm{C}\right.$ mg chl $a^{-1} \mathrm{~h}^{-1}$ $\left(\mu \mathrm{mol} \text { photons } \mathrm{m}^{-2} \mathrm{~s}^{-1}\right)^{-1}$ ) are the linear regression coefficients of fixation rates as a function of irradiance. ${ }^{*} p \leq 0.05$ ${ }^{* *} \mathrm{p} \leq 0.01$

\begin{tabular}{|c|c|c|c|c|c|}
\hline \multirow{2}{*}{ Phase } & \multirow{2}{*}{ Date } & \multicolumn{2}{|c|}{$\alpha^{\mathrm{NF}}$} & \multicolumn{2}{|c|}{$-\alpha^{\mathrm{CF}}$} \\
\hline & & BL & DB & BL & DB \\
\hline \multirow[t]{2}{*}{ Stage I } & $10 \mathrm{Jun}^{\mathrm{a}}$ & $6.70^{*}$ & $2.62^{*}$ & $41.94^{*}$ & $45.97^{*}$ \\
\hline & $15 \mathrm{Jun}^{\mathrm{a}}$ & $1.52^{*}$ & $3.96^{*}$ & $19.14^{* *}$ & $24.20^{*}$ \\
\hline \multirow[t]{4}{*}{ Stage II } & 24 Jun & 0.29 & $0.14^{*}$ & & \\
\hline & 30 Jun & -0.16 & $1.16^{*}$ & & \\
\hline & $16 \mathrm{Jul}^{\mathrm{a}}$ & -0.42 & $0.23^{*}$ & 8.28 & 3.60 \\
\hline & $10 \mathrm{Aug}^{\mathrm{a}}$ & $2.98^{*}$ & $1.36^{*}$ & $1.63^{*}$ & $1.86^{* *}$ \\
\hline \multirow[t]{3}{*}{ Stage III } & 24 Aug & $0.78^{*}$ & 0.57 & & \\
\hline & 2 Sep & 0.04 & 0.63 & & \\
\hline & $15 \mathrm{Sep}^{\mathrm{a}}$ & $0.90^{*}$ & 0.56 & $15.21^{*}$ & $9.67^{*}$ \\
\hline
\end{tabular}

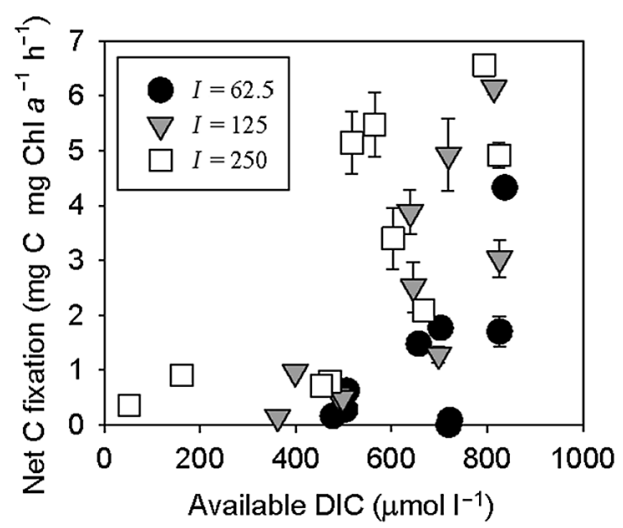

Fig. 10. The response of net $\mathrm{C}$-fixation rates at irradiances $(I)$ of $62.5,125$, and $250 \mu \mathrm{mol}$ photons $\mathrm{m}^{-2} \mathrm{~s}^{-1}$ to the available dissolved inorganic carbon (DIC). Net C-fixation rate represents the difference between gross photosynthesis in light and the dark respiration. $\mathrm{CO}_{2}$ and $\mathrm{HCO}_{3}{ }^{-}$are considered as the available DIC for cyanobacteria, which were calculated from $\mathrm{pH}$ and DIC $\left(\mathrm{p} K_{1}=6.01\right.$ for $\mathrm{H}_{2} \mathrm{CO}_{3} \leftrightarrow \mathrm{HCO}_{3}^{-}+\mathrm{H}^{+}$and $\mathrm{p} K_{2}=9.60$ for $\mathrm{HCO}_{3}^{-} \leftrightarrow \mathrm{CO}_{3}^{2-}+\mathrm{H}^{+}$). Data shown for available DIC is the average value of beginning and ending points in the daily simulation

resulted in elevated $\mathrm{pH}(>10)$ and supersaturated DO values $\left(643 \mu \mathrm{mol} \mathrm{l^{-1 }}\right)$ during incubations of dense bloom samples (Fig. 5), with the laboratory observations within the range of field data (Fig. 2). Generally, with increased irradiance, enhanced $\mathrm{pH}$ and decreased total DIC were observed during bloom Stages II and III; those changes along with the $\mathrm{pH}$ driven DIC species conversion to $\mathrm{CO}_{3}{ }^{2-}$ led to the significant decrease in bioavailable DIC $\left(\mathrm{CO}_{2}\right.$ and $\mathrm{HCO}_{3}{ }^{-}$) for cyanobacteria (Figs. 8 \& 9). The incubation irradiance was positively correlated to both average value of $\mathrm{pH}$ (corr $=0.61, \mathrm{p}<0.01, \mathrm{n}=76$ ) and $\mathrm{DO}$ (corr $=0.41, p=0.009, \mathrm{n}=69$ ), but inversely related to the average of bioavailable DIC (corr $=-0.56, \mathrm{p}<$ $0.001, \mathrm{n}=69$ ). For instance, with incubation of BL samples at $250 \mu \mathrm{mol}$ photons $\mathrm{m}^{-2} \mathrm{~h}^{-1}$ from Stage I to Stage II, daily average $\mathrm{pH}$ increased from $\sim 7.2$ to $\sim 10.5$, and the daily average DO were enhanced from $\sim 200 \mu \mathrm{mol} \mathrm{l}^{-1}$ to $>600 \mu \mathrm{mol} \mathrm{l} \mathrm{l}^{-1}$ (Fig. 5). Coincidently, the daily average bioavailable DIC concentration decreased from over $800 \mu \mathrm{mol} \mathrm{l}^{-1}$ in Stage I to $\sim 300 \mu \mathrm{mol} \mathrm{l}^{-1}$ in Stage II (Fig. 9).

\section{$\mathbf{N}_{2}$ fixation}

$\mathrm{N}_{2}$ fixation was first detected on June 10 when DIN became limiting (Figs. 6 \& 11). In the bloom initiation period (Stage I), positive relationships were observed between irradiance and $\mathrm{N}_{2}$-fixing (diazotrophic) biomass-specific $\mathrm{N}_{2}$-fixation rates (Table 3). The maximum $\mathrm{N}_{2}$-fixation rates in the $250 \mu \mathrm{mol}$ photons $\mathrm{m}^{-2}$ $\mathrm{s}^{-1}$ incubations reached up to $\sim 1800 \mathrm{pmol} \mathrm{N}$ (mg C biomass $)^{-1} \mathrm{~d}^{-1}$ in the samples from $\mathrm{BL}$ and over $\sim 900$ pmol $\mathrm{N}$ (mg C biomass) $)^{-1} \mathrm{~d}^{-1}$ in the samples from DB. In contrast, cyanobacteria in the dark fix $\mathrm{N}_{2}$ inefficiently, with fixation rates $<90$ pmol N (mg C biomass $)^{-1} \mathrm{~d}^{-1}$ and sometimes undetectable.

Compared with Stage I, biomass-specific $\mathrm{N}_{2}$-fixation rates were generally lower in Stages II and III, and appeared to decrease with rising $\mathrm{pH}$ and $\mathrm{DO}$

Table 3. Multiple linear relationships of $\mathrm{N}_{2}$-fixation (pmol $\mathrm{N}$ [mg C biomass] ${ }^{-1} \mathrm{~d}^{-1}$ ) and C-fixation rates (mg C mg chl $\mathrm{a}^{-1}$ $\mathrm{h}^{-1}$ ) environmental parameters, estimated by a forward stepwise regression. Data shown are the linear regression coefficients of biomass-specific $\mathrm{N}_{2}$-fixation rates $\left(K_{-\mathrm{NF}}\right)$ and chlorophyll a-normalized C-fixation rates $\left(K_{-\mathrm{CF}}\right)$ as a function of environmental factors. Independent variables are the daily average value of dissolved oxygen (DO), dissolved inorganic carbon (DIC), irradiance, soluble reactive phosphorus (SRP), $\mathrm{NO}_{3}{ }^{-}$, and $\mathrm{NH}_{4}{ }^{+} .{ }^{*} \mathrm{p} \leq 0.05,{ }^{* *} \mathrm{p} \leq 0.01,{ }^{* * *} \mathrm{p} \leq 0.001$

\begin{tabular}{|lcc|}
\hline Parameters & \multicolumn{1}{c|}{$K_{-\mathrm{CF}}$} & \multicolumn{1}{c|}{$K_{-\mathrm{NF}}$} \\
\hline Intercept & $-3047.44^{*}$ & $371.91^{*}$ \\
$\mathrm{DIC}$ & $8.21^{* * *}$ & $2.23^{* * *}$ \\
Irradiance & $24.15^{* * *}$ & $2.24^{* * *}$ \\
$\mathrm{DO}$ & $-13.23^{* *}$ & $-1.40^{* *}$ \\
$\mathrm{SRP}$ & $7425.74^{*}$ & $-599.31^{*}$ \\
$\mathrm{NO}_{3}{ }^{-}$ & -191.47 & $-14.12^{* *}$ \\
$\mathrm{~N}^{\mathrm{P}}$ ratio & 38.71 & -1.54 \\
$\mathrm{NH}_{4}{ }^{+}$ & 824.22 & -102.41 \\
\hline
\end{tabular}




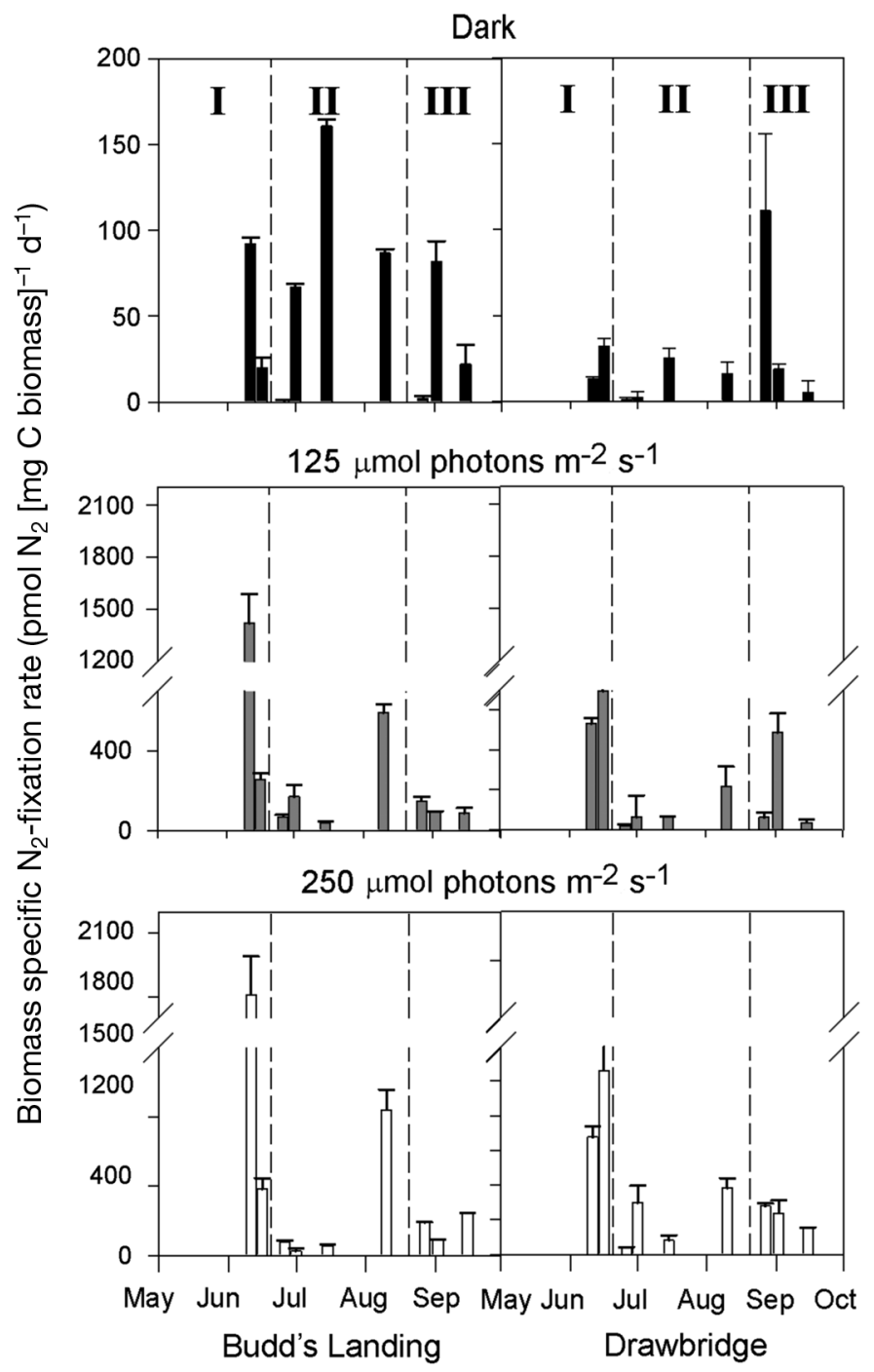

Fig. 11. $\mathrm{N}_{2}$-fixation rates at Budd's Landing and Drawbridge, including $24 \mathrm{~h}$ dark and $14 \mathrm{~h}$ light:10 $\mathrm{h}$ dark incubation at irradiances of 125 and $250 \mu \mathrm{mol}$ photons $\mathrm{m}^{-2} \mathrm{~s}^{-1}$. Note difference in $y$-axis scales. Data are shown for the bloom Stages I, II, and III. Error bars are SE

during blooms (Figs. $9 \& 11$ ). When samples were collected from high $\mathrm{pH}(>9.5)$ waters at BL on June 30 and July 14 and at both stations on September 1, $\mathrm{N}_{2}$-fixation rates dropped below 300 pmol N (mg C biomass $)^{-1} \mathrm{~d}^{-1}$ at an incubation irradiance of $250 \mu \mathrm{mol}$ photons $\mathrm{m}^{-2} \mathrm{~s}^{-1}$.

Except for the densest bloom periods, biomassspecific $\mathrm{N}_{2}$-fixation rates usually increased as a linear function of irradiance (Table 2). When waters were characterized by elevated $\mathrm{pH}$ and DO and low DIC, however, the correlations usually became weak or non-significant, such as the samples collected from BL in Stage II and both stations on September 2
(Stage III) (Figs. $2 \& 5$ ). In addition, $\mathrm{N}_{2}$-fixation rates during dense bloom periods are negatively related to the increased irradiance, which cause $\mathrm{pH}$ elevation and carbon depletion. The dark $\mathrm{N}_{2}$ fixation increased up to 160 pmol $\mathrm{N}$ (mg C biomass) ${ }^{-1} \mathrm{~d}^{-1}$. Assuming that the $\mathrm{N}_{2}$-fixation rates in the $24 \mathrm{~h}$ dark incubations were similar to the rates during the dark period of light:dark incubation, the $\mathrm{N}_{2}$ fixation during the dark period could account for up to 40 to $62 \%$ of daily $\mathrm{N}_{2}$ fixation in Stage II samples from upriver and for 20 to $45 \%$ of daily $\mathrm{N}_{2}$ fixation in samples from the downstream site when the bloom expanded during the Pseudanabaena bloom (Stage III) (Fig. 12).

\section{Environmental effects on $\mathrm{C}$ - and $\mathrm{N}_{2}$-fixation rates}

In this study, both DIC supply and irradiance showed positive effects on $\mathrm{C}$ fixation (Table 3 ); but increased irradiance resulted in higher $\mathrm{C}$ uptake and decreased DIC in the water as well (Fig. 9), creating constraints on $\mathrm{C}$ fixation. Phosphorus supply was positively related to $\mathrm{C}$ fixation and SRP concentrations decreased sharply over time, reflecting the importance of $\mathrm{P}$, especially when the water column dissolved $\mathrm{P}$ concentrations became low (Table 3). DIN was usually more limiting for cyanobacteria blooms relative to SRP in summer (Fig. 5). The data from this study showed an inverse relationship between DIN concentrations and $\mathrm{N}_{2}$-fixation rates, evidence that nitrogen limitation promoted $\mathrm{N}_{2}$ fixation (Table 3). Consistent with the decline in DIC in waters due to photosynthetic carbon uptake, there were positive relationships between the remaining DIC concentrations with both $\mathrm{C}$ - and $\mathrm{N}_{2}$-fixation rates. Meanwhile, increases in DO exerted a negative effect on $\mathrm{N}_{2}$ fixation (Table 3).

\section{DISCUSSION}

Environmental conditions in the upper, tidal freshwater Sassafras River during summer 2010 promoted the growth and persistence of cyanobacteria. Water temperature remained above $25^{\circ} \mathrm{C}$ for most of the summer. As temperatures approach and exceed $20^{\circ} \mathrm{C}$, cyanobacteria appear to be able to out compete diatoms and green algae (Coles \& Jones 2000). This is likely because the growth rates of freshwater eukaryotic phytoplankton generally plateau or decrease with warmer temperatures while growth rates of many cyanobacteria increase (Paerl \& Huisman 2008, O'Neil et al. 2012). 


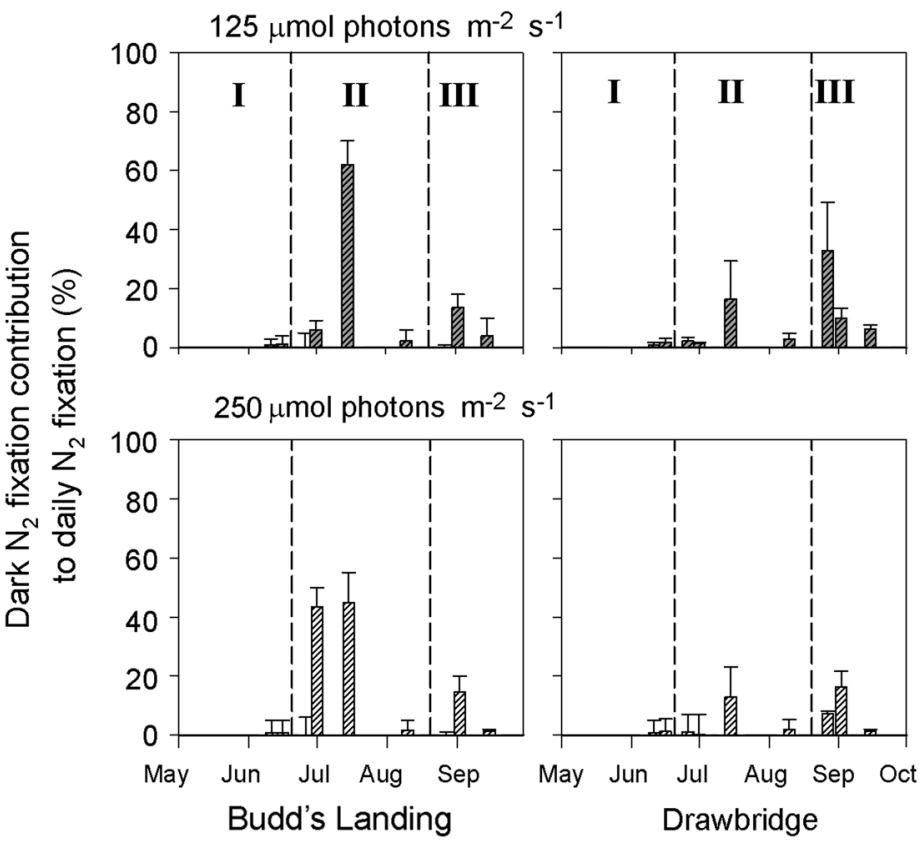

Fig. 12. Contribution of dark $\mathrm{N}_{2}$ fixation to daily $\mathrm{N}_{2}$ fixation at Budd's Landing and Drawbridge. Assuming the $\mathrm{N}_{2}$-fixation rate in the $24 \mathrm{~h}$ dark incubation was equal to that in the dark period of the $24 \mathrm{~h}$ light:dark incubation, accumulation of fixed $\mathrm{N}$ in the $10 \mathrm{~h}$ dark was compared with the daily $\mathrm{N}$ fixation in the dark:light incubation at each light level (125 and $250 \mu \mathrm{mol}$ photons $\mathrm{m}^{-2} \mathrm{~s}^{-1}$ ). Data are shown for the bloom Stages I, II, and III

Salinity in the summer was suitable for cyanobacteria growth, evidenced by the temporal changes and spatial distribution. Overall, cyanobacteria bloomed when salinity reached its low point for the season in late June to mid-August. Cyanobacteria were more abundant at the lower salinity, upriver site than downriver, at the slightly more saline site. Estuarine cyanobacteria blooms are usually dominated by freshwater strains whose growth rates are reduced as salinity increases above 1 to 2 (Sellner et al. 1988). However, some estuarine strains of cyanobacteria can persist over a wide range of salinity. Microcystis sp. can survive salinity ranges from 0 to 14 (Tonk et al. 2007) and Anabaena sp. can survive salinity ranges of 0 to 20 (Marino et al. 2002, Moisander et al. 2002). Tidal salinity oscillations and seasonal changes in the upper Sassafras River may favor cyanobacteria over less-salt-tolerant freshwater or marine eukaryotic phytoplankton (Tonk et al. 2007).

Nutrient supply and N:P ratios are important factors regulating species composition and bloom development. As DIN:SRP ratios decreased during the summer bloom, this ecosystem turned from P limitation to $\mathrm{N}$ limitation, which led to a succession from non- $\mathrm{N}_{2}$ fixers, such as Microcystis spp., to diazo- trophs, such as Anabaena spp., Pseudoanabaena sp. and Synechococcus sp. The fixed N from diazotrophs can be released into the water as $\mathrm{NH}_{4}{ }^{+}$, amino acids or other organic $\mathrm{N}$ compounds (Carpenter et al. 1999), which can be assimilated by the surrounding microbial community (Mulholland et al. 2004). This may possibly account for the co-occurrence of non$\mathrm{N}_{2}$-fixing cyanobacteria and eukaryotic phytoplankton with $\mathrm{N}_{2}$-fixing cyanobacteria during blooms (Howarth et al. 1988).

In the summer, when dissolved inorganic nutrients were low, $\mathrm{N}_{2}$-fixing cyanobacteria were more prevalent at the upper river than the downriver sites. BL is shallower (0.8 to $1.4 \mathrm{~m}$ ) and had a higher water column $\mathrm{pH}$ (9.5 to 10.5) than the downstream DB site. At the BL site, persistent high $\mathrm{pH}$ may continuously drive $\mathrm{P}$ release from sediments and suspended particles may help supply P for cyanobacteria consumption, satisfying a large proportion of $\mathrm{P}$ demand during cyanobacteria blooms (Seitzinger 1991, Gao et al. 2012). The N:P ratios were lower and nutrient release from sediments was higher at the BL than DB site, potentially favoring the growth of $\mathrm{N}_{2}$ fixers at the upriver BL site (Gao et al. 2014).

This investigation focused on changes in $\mathrm{C}$ and $\mathrm{N}_{2}$ fixation, interactions between $\mathrm{C}$ - and $\mathrm{N}_{2}$-fixation rates, and the relationship of these rates to changes in cyanobacteria species composition during the course of the bloom over the summer. The positive responses in $\mathrm{C}$ fixation to increased light in Stage I were consistent with previous studies (Lewis 1984, Coles \& Jones 2000). The range of photosynthesis rates observed was similar to observations of 1.4 to $24.5 \mathrm{mg} \mathrm{C} \mathrm{mg} \mathrm{chl} a^{-1} \mathrm{~h}^{-1}$ during a cyanobacterial summer bloom in the tidal freshwater zone of the Potomac River (Jones 1998). Our photosynthetic efficiencies $\left(\alpha^{\mathrm{CF}}\right)$ were below or close to those reported from cyanobacterial blooms ( 2.8 to $14.4 \mathrm{mg} \mathrm{C} \mathrm{mg} \mathrm{chl}$ $a^{-1} \mathrm{~h}^{-1}$ ( $\mu \mathrm{mol}$ photons $\left.\mathrm{m}^{-2} \mathrm{~s}^{-1}\right)^{-1}$ ) and cyanobacteria cultures (6.5 to $14.4 \mathrm{mg} \mathrm{C} \mathrm{mg} \mathrm{chl} a^{-1} \mathrm{~h}^{-1}$ (umol photons $\left.\left.\mathrm{m}^{-2} \mathrm{~s}^{-1}\right)^{-1}\right)$ (Oh et al. 1991, Coles \& Jones 2000, Sabour et al. 2009).

As blooms develop, photosynthetic $\mathrm{C}$ uptake leads to decreased DIC concentrations and elevated $\mathrm{pH}$ (Ploug 2008, O'Neil et al. 2012). In Stage II, the shift from $\mathrm{HCO}_{3}{ }^{-}$towards $\mathrm{CO}_{3}{ }^{2-}$ under high $\mathrm{pH}(>9.5)$ and reduced DIC concentrations at $\mathrm{BL}$ resulted in depletion of available inorganic carbon $\left(\mathrm{CO}_{2}\right.$ and $\left.\mathrm{HCO}_{3}{ }^{-}\right)$. Meanwhile, C-fixation rates correlated more to DIC availability than to incubation irradiance, suggesting 
that the combination of limited DIC availability and high $\mathrm{pH}$ caused a substrate shortage for photosynthesis. Although cyanobacteria have carbonconcentrating mechanisms that improve the efficiency of $\mathrm{CO}_{2}$ fixation under these conditions, the results of this study showed that severe $\mathrm{C}$ limitation during high biomass blooms in tidal freshwater estuaries can reduce photosynthetic C-uptake efficiency. Similarly in culture studies, $\mathrm{C}$ limitation and high $\mathrm{pH}$ can inhibit growth, cell division, and photosynthesis of freshwater cyanobacteria (Qiu \& Gao 2002, Yamamoto \& Nakahara 2005).

The increase in $\mathrm{N}_{2}$-fixation rates with irradiance in Stage I of the bloom was consistent with field studies of $\mathrm{N}_{2}$ fixation during Anabaena spp.-dominated blooms in fresh water (Severin \& Stal 2008). The positive relationship between $\mathrm{C}$ and $\mathrm{N}_{2}$ fixation (Table 4) suggests a co-dependence of 2 processes. $\mathrm{N}_{2}$ fixation has a high energy and carbon demand from photosynthesis (Bothe et al. 2010); the formation of ammonium through $\mathrm{N}_{2}$ reduction, in return, supports growth and photosynthesis of the cyanobacteria community.

From late Stage I to Stage II of the bloom, the dominance of Anabaena spp. and the higher $\mathrm{N}_{2}$ fixation in the light bottles than dark bottles are probably related to their ability to carry out oxygenic photosynthesis and $\mathrm{N}_{2}$ fixation concurrently during the day. Anabaena spp. can fix nitrogen within specialized heterocysts, which have lost the $\mathrm{O}_{2}$-evolving photosystem II and retain photosystem I, thereby protecting the nitrogenase from oxygen and converting light into energy to support $\mathrm{N}_{2}$ fixation (Adams \& Duggan 1999). Moreover, the cell envelope of heterocysts represents a gas diffusion barrier, and any $\mathrm{O}_{2}$ that enters the cell is scavenged by an efficient and high-affinity respiratory system (Staal et al. 2003). All those properties favor nitrogenase reduction in the light.

Table 4. Response of $\mathrm{N}_{2}$ fixation to $\mathrm{C}$ fixation in the laboratory incubation of samples collected during bloom Stages I, II, and III at 2 stations in Budd's Landing (BL) and Drawbridge (DB). Data shown are the correlation coefficients between $\mathrm{N}_{2}$ - and C-fixation rates. ${ }^{*} \mathrm{p} \leq 0.05,{ }^{* *} \mathrm{p} \leq 0.01$

\begin{tabular}{|llcl|}
\hline \multirow{2}{*}{ Phase } & Date & \multicolumn{3}{c|}{$\begin{array}{c}\text { Correlation: } \\
\text { BL }\end{array}$} & Ds. C fixation \\
& & DB \\
\hline \multirow{2}{*}{ Stage I } & 10 June & $0.14^{*}$ & $0.06^{* *}$ \\
& 15 June & $0.07^{*}$ & $0.13^{*}$ \\
Stage II & 16 July & $-0.05^{*}$ & 0.03 \\
& 30 August & 0.68 & $0.74^{*}$ \\
Stage III & 15 September & 0.05 & 0.05 \\
\hline
\end{tabular}

In the incubations with high biomass bloom samples (Table 4), particularly during the high $\mathrm{pH}$ and low DIC periods of Stages II and III, DIC limitation of photosynthesis may have resulted in a decrease in $\mathrm{N}_{2}$ fixation. $\mathrm{N}_{2}$ fixation has a high energy demand (16 mol ATP for the reduction of $1 \mathrm{~mol} \mathrm{~N}_{2}$ ) (Bergman et al. 1997), and requires the photosynthetic production of 'assimilatory power' (ATP and reducing equivalents in the form of NADPH or reduced ferredoxin). In culture studies of marine cyanobacteria, limited DIC availability can inhibit cyanobacteria growth, C fixation, and $\mathrm{N}_{2}$ fixation (Levitan et al. 2007, Fu et al. 2008). Moreover, light-stimulated oxygen accumulation during blooms may constrain nitrogenase activity (Paerl \& Zehr 2000). In addition, the high $\mathrm{pH}$ caused by DIC removal via photosynthetic uptake can lead to precipitation of essential trace elements, which may consequently inhibit the physiological activities of cyanobacteria (Stumm \& Morgan 1996). For example, shortages in dissolved iron and molybdenum can limit $\mathrm{N}_{2}$ fixation by cyanobacteria (Berman-Frank et al. 2007, Bothe et al. 2010).

Dark $\mathrm{N}_{2}$ fixation became increasingly important as the bloom reached high biomass, oxygen became supersaturated, and pH increased to >9.5. Synechocystis sp., a unicellular diazotrophic cyanobacteria, became more abundant in Stage II at BL and in Stage III at DB. Synechocystis sp. and Chroococcus spp. can temporally separate photosynthesis and $\mathrm{N}_{2}$ fixation, with the latter occurring in darkness (Capone et al. 2009). Shifts in $\mathrm{N}_{2}$ fixation from light to dark during $24 \mathrm{~h}$ incubations may have minimized the deleterious effects of $\mathrm{O}_{2}$ on nitrogenase activity. Alternatively, relatively higher $\mathrm{N}_{2}$-fixation rates may occur at the beginning of dark incubations. Once light is no longer available, dark respiration may alleviate oxygen stress by consuming intracellular $\mathrm{O}_{2}$ and decreasing DO concentrations in the water (Fay 1992). Excess energy produced during the light period may also become available and cover part of the energy demand of $\mathrm{N}_{2}$ fixation in the dark (Paerl 1996). For example, heterocystous Anabaena spp. and non-heterocystous Oscillatoria limosa, Limnothrix aestuarii, and Lyngbya aestuarii may fix N more efficiently right after the switch from long-period light incubation to dark (Bergman et al. 1997, Staal et al. 2003).

Although heterotrophic bacteria have low $\mathrm{N}_{2}$ fixation rates relative to cyanobacteria diazotrophs, their respiration may help maintain suitable conditions for photosynthesis and $\mathrm{N}_{2}$ fixation within the cyanobacteria consortium (Paerl 1977). Under high 
$\mathrm{pH}$ and low DIC conditions, bacterial association may provide zones of increased $\mathrm{CO}_{2}$ availability coupled with $\mathrm{O}_{2}$ removal through mineralization of organics, which may provide protection from $\mathrm{O}_{2}$ inhibition of nitrogenase activity and relax $\mathrm{C}$ limitation. In turn, diazotrophs may release surplus nitrogen to the heterotrophic community (Falcón et al. 2004).

Although $\mathrm{N}_{2}$ fixers can balance their assimilation of $\mathrm{C}$ and $\mathrm{N}$ during blooms by accessing reservoirs of atmospheric dissolved $\mathrm{N}_{2}$ and $\mathrm{CO}_{2}$ (Klemer et al. 1996), particulate $\mathrm{C}: \mathrm{N}$ ratios under high $\mathrm{pH}$ and low DIC decreased to approximately Redfield ratio values. These changes could be due to the reduced carbon availability (Burkhardt et al. 1999). The low particulate N:P ratio during Stage II is consistent with $\mathrm{N}$ limitation in the water column and SRP enrichment due to $\mathrm{pH}$ elevation. In September, a clear excess of DIN relative to SRP at BL and a decrease in temperature may end the blooms.

This study focused on cyanobacteria species composition, inorganic nutrients, temperature, and salinity as the factors that fostered the growth and persistence of cyanobacteria blooms in the upper Sassafras River. However, biotic interactions may also be important to the timing and location of estuarine cyanobacteria blooms. Release from topdown control by grazing has been shown to be a factor contributing to the proliferation of cyanobacteria in oligohaline and tidal freshwaters. In more saline parts of estuaries, grazing by the copepod Acartia tonsa can prevent the net growth of filamentous, colonial cyanobacteria such as Anabaena (Marino et al. 2002, Chan et al. 2006), but Microcystis and Anabaena spp. can produce toxins that may inhibit grazing. However, not all strains are toxic (Tango \& Butler 2008). The MD DNR monitors the Sassafras River during dense cyanobacteria blooms, but toxic events were not reported in summer 2010. Furthermore, even in the absence of high toxicity, dense cyanobacteria blooms can have negative effects on other planktonic organisms. Mogelhoj et al. (2006) found that high $\mathrm{pH}$ during blooms, which were observed in the present study, can be responsible for many of the negative effects of cyanobacteria blooms on competitors and grazers. Hence, once cyanobacteria blooms reach high biomass, high $\mathrm{pH}$ and/or toxicity may reduce both competition with other phytoplankton and mortality due to grazing, allowing the bloom to persist even if specific growth rates of the cyanobacteria are reduced because of nutrient or inorganic carbon limitation.

\section{CONCLUSIONS}

During summer 2010, a persistent and mixedspecies cyanobacteria bloom occurred in the oligohaline and tidal freshwater reaches of the Sassafras River. The cyanobacteria consortium was able to establish dominance in early summer when $\mathrm{N}$ became limited and formed a high biomass that persisted for months. Photosynthesis by the high biomass blooms caused the elevations in $\mathrm{pH}$ and oxygen. However, both reductions in the biomass-specific $\mathrm{N}_{2}$ and chl anormalized C-fixation rates imply that the bloomdriven $\mathrm{pH}$ elevation and DO oversaturation caused negative feedbacks on cyanobacteria growth. Dark $\mathrm{N}_{2}$ fixation, mediated by diazotrophic species succession and their various physiological adaptations, appeared to supply the 'missing' nitrogen during dense blooms. The presence of a mixture of species allowed the consortium to exploit both seasonal and diel windows in environmental conditions for photosynthesis, $\mathrm{N}_{2}$ fixation, and growth. Overall, the cyanobacteria bloom created conditions unsuitable for growth of most other phytoplankton, giving the cyanobacteria a competitive advantage that they are able to exploit to dominate and persist in the oligohaline region of the Sassafras River for the summer season.

Acknowledgements. This research was funded by the Maryland Sea Grant (R/EH-9). We thank Ji Li, Alison Weigel, Robert Gutierrez, and Todd Kana from University of Maryland Center for Environmental Science (UMCES), Horn Point Laboratory for sampling and analytical assistance. $\mathrm{Mr}$ Bruce Michael from the Maryland Department of Natural Resources provided the historical phytoplankton dataset. Ms Kascie Herron from the Sassafras River Association and Ms Elizabeth Brunner from the Maryland Sea Grant Research Experience for Undergraduate program helped us with sample collection. This is contribution number 4843 from UMCES.

\section{LITERATURE CITED}

Adams DG, Duggan PS (1999) Heterocyst and akinete differentiation in cyanobacteria. New Phytol 144:3-33

> Bergman B, Gallon JR, Rai AN, Stal LJ (1997) $\mathrm{N}_{2}$ fixation by non-heterocystous cyanobacteria. FEMS Microbiol Rev 19:139-185

$>$ Berman-Frank I, Quigg A, Finkel ZV, Irwin AJ, Haramaty L (2007) Nitrogen-fixation strategies and Fe requirements in cyanobacteria. Limnol Oceanogr 52:2260-2269

Bothe H, Schmitz O, Yates MG, Newton WE (2010) Nitrogen fixation and hydrogen metabolism in cyanobacteria. Microbiol Mol Biol Rev 74:529-551

Boynton WR, Kemp WM (2009) Estuaries. In: Capone D, Bronk D, Mulholland M, Carpenter E (eds) Nitrogen in the marine environment. Elsevier, Burlington, MA, p 809-866 
Breitbarth E, Mills MM, Friedrichs G, LaRoche J (2004) The Bunsen gas solubility coefficient of ethylene as a function of temperature and salinity and its importance for nitrogen fixation assays. Limnol Oceanogr Methods 2:282-288

Burkhardt S, Zondervan I, Riebesell U (1999) Effect of $\mathrm{CO}_{2}$ concentration on $\mathrm{C}: \mathrm{N}: \mathrm{P}$ ratio in marine phytoplankton: a species comparison. Limnol Oceanogr 44:683-690

Capone DG (1995) Determination of nitrogenase activity in aquatic samples using the acetylene reduction procedure. In: Kemp P, Sherr B, Sherr E, Cole J (eds) Handbook of methods in aquatic microbial ecology. Lewis Publishers, Boca Raton, FL, p 621-610

Capone D, Bronk D, Mulholland M, Carpenter E (2009) Nitrogen in the marine environment. Elsevier, Burlington, MA

> Carpenter EJ, Montoya JP, Burns J, Mulholland MR, Subramaniam A, Capone DG (1999) Extensive bloom of a $\mathrm{N}_{2}$ fixing diatom/cyanobacterial association in the tropical Atlantic Ocean. Mar Ecol Prog Ser 185:273-283

> Chan F, Marino RL, Howarth RW, Pace ML (2006) Ecological constraints on planktonic nitrogen fixation in saline estuaries. II. Grazing controls on cyanobacterial population dynamics. Mar Ecol Prog Ser 309:41-53

Codd GA, Morrison LF, Metcalf JS (2005) Cyanobacterial toxins: risk management for health protection. Toxicol Appl Pharmacol 203:264-272

Coles JF, Jones RC (2000) Effect of temperature on photosynthesis-light response and growth of four phytoplankton species isolated from a tidal freshwater river. J Phycol 36:7-16

Delwiche L, Slaughter S (2003) The little SAS book: a primer. SAS Press, Cary, NC

> Dyhrman ST, Haley ST (2006) Phosphorus scavenging in the unicellular marine diazotroph Crocosphaera watsonii. Appl Environ Microbiol 72:1452-1458

Engel A, Schulz KG, Riebesell U, Bellerby R, Delille B, Schartau M (2008) Effects of $\mathrm{CO}_{2}$ on particle size distribution and phytoplankton abundance during a mesocosm bloom experiment (PeECE II). Biogeosciences 5: 509-521

Falcón LI, Carpenter EJ, Cipriano F, Bergman B, Capone DG (2004) $\mathrm{N}_{2}$ fixation by unicellular bacterioplankton from the Atlantic and Pacific oceans: phylogeny and in situ rates. Appl Environ Microbiol 70:765-770

> Fay P (1992) Oxygen relations of nitrogen-fixation in cyanobacteria. Microbiol Rev 56:340-373

> Fu FX, Mulholland MR, Garcia NS, Beck A and others (2008) Interactions between changing $\mathrm{pCO}_{2}, \mathrm{~N}_{2}$ fixation, and Fe limitation in the marine unicellular cyanobacterium Crocosphaera. Limnol Oceanogr 53:2472-2484

Gao Y, Cornwell JC, Stoecker DK, Owens MS (2012) Effects of cyanobacterial-driven $\mathrm{pH}$ increases on sediment nutrient fluxes and coupled nitrification-denitrification in a shallow fresh water estuary. Biogeosciences 9:2697-2710

> Gao Y, Cornwell JC, Stoecker DK, Owens MS (2014) Influence of cyanobacteria blooms on sediment biogeochemistry and nutrient fluxes. Limnol Oceanogr 59:959-971

Gronberg G, Annadotter H (2006) Manual on aquatic cyanobacteria: a photo guide and a synopsis of their toxicology. Intergovernmental Oceanographic Commission of UNESCO and International Society for the Study of Harmful Algae, Copenhagen

Guillard RRL, Sieracki MS (2005) Counting cells in cultures with the light microscope. In: Andersen RA (ed) Algal culturing techniques. Elsevier-Academic Press New York, NY, p 239-252

Hillebrand H, Durselen CD, Kirschtel D, Pollingher U, Zohary T (1999) Biovolume calculation for pelagic and benthic microalgae. J Phycol. 35:403-424

Hofmann AF, Soetaert K, Middelburg JJ, Meysman FJR (2010) An aquatic acid-base modelling environment in R. Aquat Geochem 16:507-546

Howarth RW, Marino R, Lane J, Cole JJ (1988) Nitrogen-fixation in fresh-water, estuarine, and marine ecosystems. 1. Rates and importance. Limnol Oceanogr 33:669-687

Jones RC (1998) Seasonal and spatial patterns in phytoplankton photosynthetic parameters in a tidal freshwater river. Hydrobiologia 364:199-208

Kana TM, Darkangelo C, Hunt MD, Oldham JB, Bennett GE, Cornwell JC (1994) Membrane inlet mass spectrometer for rapid high-precision determination of $\mathrm{N}_{2}, \mathrm{O}_{2}$, and $\mathrm{Ar}$ in environmental water samples. Anal Chem 66:4166-4170

Klemer AR, Cullen JJ, Mageau MT, Hanson KM, Sundell RA (1996) Cyanobacterial buoyancy regulation: the paradoxical roles of carbon. J Phycol 32:47-53

> Krauk JM, Villareal TA, Sohm JA, Montoya JP, Capone DG (2006) Plasticity of N:P ratios in laboratory and field populations of Trichodesmium spp. Aquat Microb Ecol 42: 243-253

Levitan O, Rosenberg G, Setlik I, Setlikova E and others (2007) Elevated $\mathrm{CO}_{2}$ enhances nitrogen fixation and growth in the marine cyanobacterium Trichodesmium. Glob Change Biol 13:531-538

> Lewis WM (1984) The light response of nitrogen fixation in Lake Valencia, Venezuela. Limnol Oceanogr 29:894-900

Marino R, Chan F, Howarth RW, Pace M, Likens GE (2002) Ecological and biogeochemical interactions constrain planktonic nitrogen fixation in estuaries. Ecosystems 5: 719-725

> Mogelhoj M, Hansen P, Henriksen P, Lundholm N (2006) High $\mathrm{pH}$ and not allelopathy may be responsible for negative effects of Nodularia spumigena on other algae. Aquat Microb Ecol 43:43-54

> Moisander PH, McClinton E, Paerl HW (2002) Salinity effects on growth, photosynthetic parameters, and nitrogenase activity in estuarine planktonic cyanobacteria. Microb Ecol 43:432-442

Mulholland MR, Bronk DA, Capone DG (2004) Dinitrogen fixation and release of ammonium and dissolved organic nitrogen by Trichodesmium IMS101. Aquat Microb Ecol 37:85-94

O'Neil JM, Davis TW, Burford MA, Gobler CJ (2012) The rise of harmful cyanobacteria blooms: the potential roles of eutrophication and climate change. Harmful Algae 14: 313-334

Oh H, Maeng J, Rhee G (1991) Nitrogen and carbon fixation by Anabaena sp. isolated from a rice paddy and grown under P and light limitations. J Appl Phycol 3:335-343

> Paerl HW (1977) Role of heterotrophic bacteria in promoting $\mathrm{N}_{2}$-fixation by Anabaena in aquatic habitats. Microb Ecol 4:215-231

> Paerl HW (1996) Microscale physiological and ecological studies of aquatic cyanobacteria: macroscale implications. Microsc Res Tech 33:47-72

Paerl H (2008) Nutrient and other environmental controls of harmful cyanobacterial blooms along the freshwatermarine continuum. In: Hudnell K (ed) Cyanobacterial harmful algal blooms: state of the science and research needs, Vol 619. Springer, Triangle Park, NC, p 217-237 
Paerl HW, Huisman J (2008) Climate: blooms like it hot. Science 320:57-58

Paerl H, Zehr JP (2000) Marine nitrogen fixation. In: Kirchman D (ed) Microbial ecology of the oceans. Wiley-Liss, New York, NY, p 387-418

Parsons TR, Maita Y, Lalli CM (1984) A manual of chemical and biological methods for seawater analysis. Pergamon Press, New York, NY

Ploug H (2008) Cyanobacterial surface blooms formed by Aphanizomenon sp. and Nodularia spumigena in the Baltic Sea: small-scale fluxes, $\mathrm{pH}$, and oxygen microenvironments. Limnol Oceanogr 53:914-921

Qiu BS, Gao KS (2002) Effects of $\mathrm{CO}_{2}$ enrichment on the bloom-forming cyanobacterium Microcystis aeruginosa (Cyanophyceae): physiological responses and relationships with the availability of dissolved inorganic carbon. J Phycol 38:721-729

Sabour B, Sbiyyaa B, Loudiki M, Oudra B, Belkoura M, Vasconcelos V (2009) Effect of light and temperature on the population dynamics of two toxic bloom forming cyanobacteria - Microcystis ichthyoblabe and Anabaena aphanizomenoides. Chem Ecol 25:277-284

Sañudo-Wilhelmy SA, Tovar-Sanchez A, Fu FX, Capone DG, Carpenter EJ, Hutchins DA (2004) The impact of surface-adsorbed phosphorus on phytoplankton Redfield stoichiometry. Nature 432:897-901

Seitzinger SP (1991) The effect of pH on the release of phos-

Editorial responsibility: Douglas Capone,

Los Angeles, California, USA phorus from Potomac estuary sediments: implications for blue-green-algal blooms. Estuar Coast Shelf Sci 33: 409-418

Sellner KG, Lacouture RV, Parrish CR (1988) Effects of increasing salinity on a cyanobacteria bloom in the Potomac River estuary. J Plankton Res 10:49-61

Severin I, Stal LJ (2008) Light dependency of nitrogen fixation in a coastal cyanobacterial mat. ISEM J 2:1077-1088

Staal M, Hekkert STL, Harren FJM, Stal LJ (2003) Effects of $\mathrm{O}_{2}$ on $\mathrm{N}_{2}$ fixation in heterocystous cyanobacteria from the Baltic Sea. Aquat Microb Ecol 33:261-270

Stumm W, Morgan J (1996) Aquatic chemistry: chemical equilibria and rates in natural waters. John Wiley \& Sons, New York, NY

> Tango PJ, Butler W (2008) Cyanotoxins in tidal waters of Chesapeake Bay. Northeast Nat 15:403-416

> Tonk L, Bosch K, Visser PM, Huisman J (2007) Salt tolerance of the harmful cyanobacterium Microcystis aeruginosa. Aquat Microb Ecol 46:117-123

> Verity PG, Robertson CY, Tronzo CR, Andrews MG, Nelson JR, Sieracki ME (1992) Relationships between cell-volume and the carbon and nitrogen-content of marine photosynthetic nanoplankton. Limnol Oceanogr 37:1434-1446

Yamamoto Y, Nakahara H (2005) Competitive dominance of the cyanobacterium Microcystis aeruginosa in nutrientrich culture conditions with special reference to dissolved inorganic carbon uptake. Phycol Res 53:201-220

Submitted: April 24, 2013; Accepted: February 20, 2014

Proofs received from author(s): April 19, 2014 